\title{
Investigating Karanis Necropolis in a Pagan Christian Context
}

\begin{tabular}{c}
\hline Nashwa M. S. Solieman \\
Faculty of Tourism and Hotels, Menofia University \\
\hline
\end{tabular}

\begin{abstract}
:
Cemeteries have long interested scholars from such diverse fields as Archaeology, art history, cultural geography, anthropology, history, and those concerned with heritage conservation. These experts recognize that by studying cemeteries and their artifacts, they can learn a culture's attitudes toward life through its responses to death. They understand that a society's behavior in the interment of its dead reveals its cultural values. Every aspect of the cemetery reflects the culture that created it, even its orientation. The following paper is an attempt to throw light on the necropolis of ancient Karanis since no comprehensive archaeological or descriptive documentation was previously done. All scanty references depended on a weak reconnaissance derived from the 1900's work of B.P. Grenfell, A.S. Hunt and D.G. Hogarth. The main aim of the new investigation therefore is a detailed consideration of the necropolis, its dating, its artifacts and also marking it on the general sketch plan of the site trying to provide further insight into mortuary practices adopted by the community of Karanis in its late phase of occupation in the light of new discoveries' investigation side by side with the proceeding of data gathered from the old excavations and what is known of such practices in Egypt.
\end{abstract}

Keywords: Late Antiquity, Greaco-Roman Egypt, Coptic, Karanis, necropolis

\section{Introduction:}

The village of Karanis occupies a unique place in the annals of Egyptian archaeology. It has long been recognized as critical for the documentation of the material culture of Graeco-Roman and early

- I wish to express my profound acknowledgement to Prof Dr. Zahi Hawass, General Secretary of the Supreme Council of Antiquities for granting permission to study the necropolis of Karanis and to visit and photograph the site and get acquainted with the reports available. Especial thanks are also due to all of the staff in the Inspectorate of Fayum Antiquities for their support and fruitful cooperation, especially Mr. Ahmed Abdel Aal, the General Director of the Inspectorate for providing full access to the Main inventories and site records and for assigning an inspector to accompany and guide at the site. I am also indebted to all staff of Kom Aushim museum.

مجلة كلية السياحة والفنادق - جامعة الإسكندرية - سبتمبر • + ؟ 
Christian Egypt being a copious source of information about Egyptian villages up to Late Antiquity. Its history spans seven centuries, from the middle of the $3^{\text {rd }}$ century $\mathrm{BC}$ to the end of the $5^{\text {th }}$ century $\mathrm{AD}$ or the early $6^{\text {th }}$ century AD. From the perspective of contextual archaeology, the remains of Karanis have captivated Egyptologists and Classical archaeologists since the discovery of the site in the end of the $19^{\text {th }}$ century. Since then the site has remained the focus of scholarly studies. In this regard Roger S. Bagnall eloquently stated that apart from the Fayum, it was even hard to find an extensively studied village, and there one could hardly point to anything but Karanis. ${ }^{1}$

Post-excavation analyses and interpretations of Karanis have focused on the extensive archaeological, documentary and material data with the result that the reconstruction of the environment of life in the site has been greatly embodied. ${ }^{2}$ However, this has usually been at the expense of the mortuary context. Hardly one finds any references to burial practices adopted by the community of Karanis. How they treated the dead and what they believe about the afterlife. Apart from the hints mentioned by D. G. Hogarth in Fayum Towns and their Papyri in $1900^{3}$, no mention of the necropolis of Karanis was made in any scholarly publication. ${ }^{4}$ Even the reports of the archaeological mission of Michigan University provide no benefit in this regard; only the reference of devoting a day in 1925 to dig the town's graves, but there have not been disclosed any detailed information than that the unearthed graves were of a rather modest type, and retained skeletons so far in good state of preservation. ${ }^{5}$

El-Nassery in his survey report of the third season of the excavations carried out by Alexandria University in 1972 briefly states that the mission was able to identify some features of the cemetery but regrettably the little value recovered from the graves led to the suspension of exploration just ten days after it was started. ${ }^{6}$

1 Bagnall R.S. (2001), p. 227.

2 Papyrological (e.g.): Youtie H.C., et al. (1936-1939); Youtie H.C., Pearl O.M. (1944); Youtie H.C., Winter J.G. (1951); Husselman E.M (1971); Also PhD dissertation in Arabic

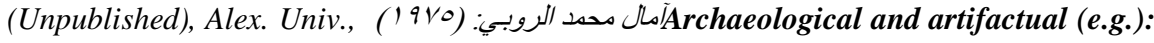
Allen M.L. (1985) [terracotta figurines]; Gazda E.K. (1978) [sculptures]; Haatvedt R.A., Peterson E.E. (1964) [coins]; Harden D.L. (1936) [glass]; Johnson B. (1981) [pottery]; Shier L.A. (1978) [terracotta lamps].

3 Grenfell B. P. et al (1900), pp. 40-42

4 Even the unpublished doctoral dissertation cited above in ft.note2. It is an analytical study of papyri focused on the socio-economic approach of Karanis without any reference of how society responses to death or its behavior in the interment of the dead.

5 Boak, A.E., Peterson E.E. (1931), p.4

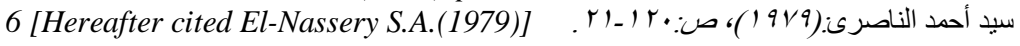

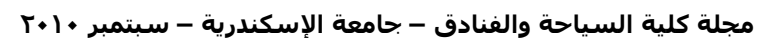


Also Paola Davoli's 1998 book on the Graeco-Roman sites in Fayum region did not add much about the necropolis of Karanis, even though she devoted a chapter for Karanis regarding it as the only site satisfactorily excavated so far, pointing out how poorly pre-Roman levels are known being usually covered by Roman remains. ${ }^{1}$ As for the necropolis, Davoli also referred to the Grenfell-Hunt-Hogarth excavations, adding that a probable Coptic necropolis was discovered and excavated in 1972 by Cairo University (under direction of S.A.A. El-Nassery). She appended a short footnote mentioning the scarcity of information on these graves and that there is no published plan of the necropolis. She also hinted that excavations have recently been remade by the Inspectorate of the Fayum in the northern necropolis with no more information than that they found Coptic inscription among the graves which might retain the name of the deceased. ${ }^{2}$

Since then, no more mention had been made of the necropolis of Karanis until 2005, when the subject is concisely discussed by Manal M. Abdel Hamid in an unpublished master's thesis of Alexandria University, where the researcher confirmed the lack of sufficient information on the graves of the village and attributed that for the limited financial resources allocated to support deliberate and systematic excavations of the site. ${ }^{3}$ This thorough monograph might be considered the sole multidisciplinary study of Karanis. However, the researcher with regard to the cemetery only satisfied with quoting Hoggarth and El-Nassery without in-depth analytical study. The researcher ended her topic by referring to a recent photo of the site shows the existence of some Coptic gravestones inscribed with some letters and pointed to the inability to access any further information in this concern.

Whereas the cemetery with its gravestones and artifacts is a history of people; a perpetual record of yesterday where lives are commemorated and deaths are recorded; thence, scholars from diverse fields would seek information and our heritage is thereby enriched. Therefore, the main concern of this paper is to investigate thoroughly the necropolis of Karanis, its dating, its artifacts and also marking it on the general sketch plan of the site trying to provide further insight into the burial practices adopted by the community of Karanis in its late phase of occupation.

1 Davoli P. (1998), pp. 87-116

2 Davoli P. (1998), pp. 89-90, footnotes: 136, 138

3 This dissertation presents a thorough study of Karanis, its location, nomination, Establishments, excavation and topography. It also tackled upon aspects of socio-economic life of the Karanis. منال محمود عبد الحمبي: (r.oreafter cited as Abdel Hamid M.M. (2005)].

مجلة كلية السياحة والفنادق - جامعة الإسكندرية - سبتمبر • + † 


\section{The Historical Setting:}

At the edge of the desert on the northeastern outskirts of the Fayum region (the former Arsinoite nome in antiquity) and about fifty miles southwest from the capital city of Cairo lies the mound of Kom Aushim (Fig. 1). ${ }^{1}$ It is the site of the ancient village of Karanis that was among many Greek colonies founded in the fertile Fayum basin following the reclamation of the land around the perimeter of Lake Moeris by the early Ptolemies. ${ }^{2}$

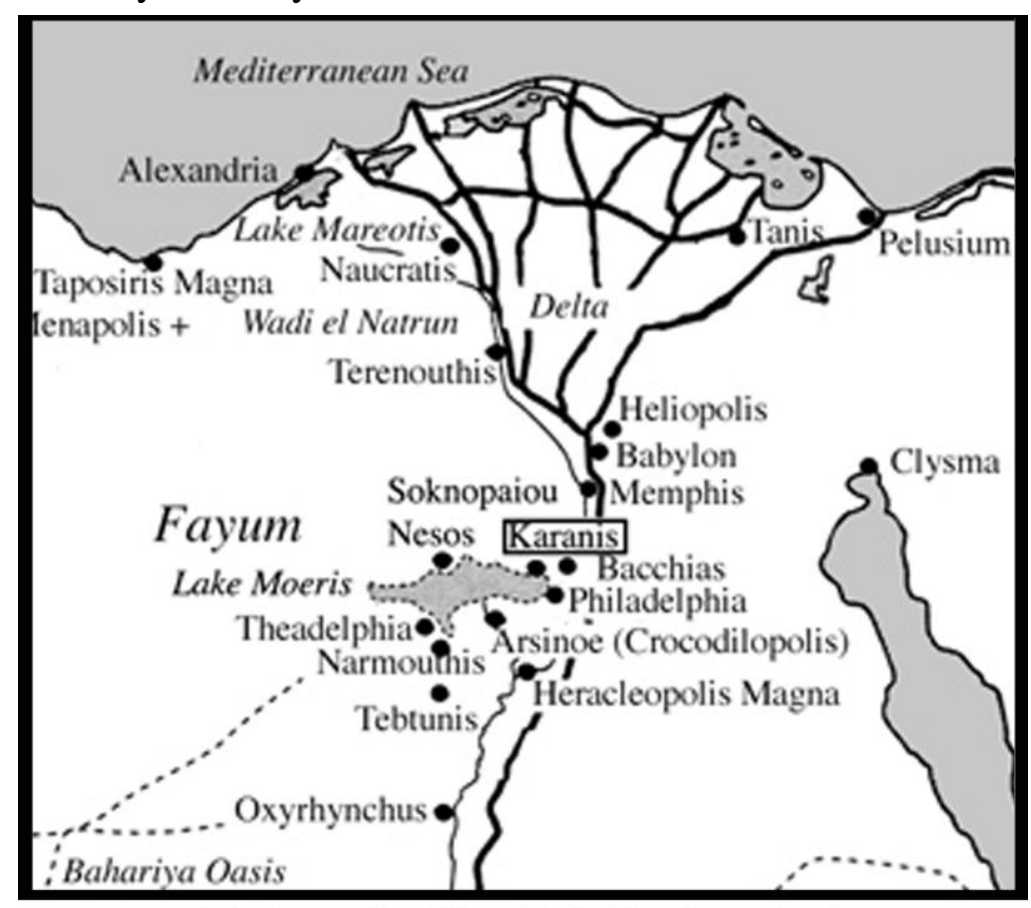

Fig.1 The Location of Karanis in the Map of Lower Egypt

(After Kelsey Museum of Archaeology)

http://www.lsa.umich.edu/kelsey/galleries/Exhibits/textiles/classroom/class1a.html\#map2

The agricultural richness of the area had long been recognized by the ancient Egyptian Kings since the middle Kingdom, and comprehensive historical records mention the Nile-fed Lake that once filled the depression of Fayum and it was called in ancient Egyptian $M r$-wr (Moipıos). ${ }^{3}$ The latter term was, according to classical literature,

1 Bard K. A., Shubert S. B. (1999), p.369

2 For references on the reclamation of the Fayum basin see: Butzer K.W. (1976), pp. 36-38, 41; Crawford D. J. (1971), p. 40.

3 Gardiner A.H, Bell H.I. (1943), 37-50 
named after Pharaoh (Ny-maat-re) Amenemhet, whom the Greeks named King Moeris. ${ }^{1}$

The Lake was thus filled with abundance of freshwater from the Nile by means of canals that were certainly vital conduits for goods trafficked between the Delta and the district. Moreover, because of its location on the caravan route north to Alexandria, the area gained access to wider Egyptian and foreign trade. ${ }^{2}$

By the time of King Ptolemy II Philadelphus in the $3^{\text {rd }}$ century BC, the lake level had been lowered so that rich alluvial soil was thus laid bare (approximately 450 square miles of it), and thus the land around the lake became fertile ready for intensive cultivation; which in other words means the developing of agriculture and the provision of food. The population around the lake thus increased at a rapid rate, and a number of new towns sprang up, especially around the northern shore where Karanis is located. ${ }^{3}$

It was established early in the third century BC as part of Ptolemy II scheme to settle Greek mercenaries among the indigenous Egyptians and to exploit the potential of the fertile Fayum basin. In this respect Karanis was also ideally situated to develop into a prospering agricultural community. It remained occupied for at least 600 years until the late $5^{\text {th }}$ or early $6^{\text {th }}$ century AD. ${ }^{4}$

The first century $\mathrm{AD}$ was a time of great building activity at Karanis, and the following centuries of Roman rule were a time of expansion and economic growth for the town. The site peaked in terms of population from the $2^{\text {nd }}$ to $4^{\text {th }}$ centuries $\mathrm{AD}$ as Roman administration continued the land reclamation and irrigation projects begun by the Ptolemies. ${ }^{5}$

As for the name Karanis, Peter Van Minnen referred to a large amount of textual evidence found in the site that explicitly mention the village by name as well as texts found elsewhere sometimes do ${ }^{6}$. In his view the name derives from Karanos, the legendary forefather of the Macedonian kings. ${ }^{7}$

Working from papyrological tax documents, its population can be judged to have fluctuated between approximately 3,300 and 1,900

1 Herodotus, II. 101, 148-50; Strabo, XVII, 1.35-37; Diodorus Siculus, I,52.

2 Harrell J.A., Bown T.M.(1995), pp.71-91; Bloxam E.G., Storemyr P. (2002), pp. 23-36. Bowman A. K. (1986), p.13

3 Hassan F. A. (1986).

4 Husselman E.M (1971), pp. 7-10; Gazda E.K., Wilfong T. (2005).

5 Westermann W.L. (1917), pp. 426-30; Geremek H., (1969), p. 7; Boak A.E. (1955), pp. 161f; id., (1926), pp. 353-363.

6 For an example see below the paragraph annotated with footnote 34 .

7 Van Minnen P. (1995), p. 47. He also adds that PtolemyII also drew on the name Karanos for one of the demes of Ptolemais.

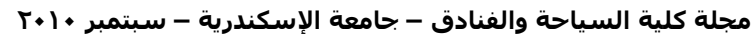


during the 2nd century, ${ }^{1}$ which is roughly equivalent to its neighboring Fayum towns. ${ }^{2}$ A mix of Greeks, Romans, and native Egyptians would have populated Karanis, like most towns of any significant size. The papyri found in abundance were Greek and Latin documentary and literary texts which presented an image of a highly Hellenized urban centre.

It is worth pointing out that by using papyrological tax documents as evidence, R.A. Alston demonstrates that $14 \%$ of the population had Latin names. ${ }^{3}$ Although this does not mean that all these people were Romans in the strict sense, it is a comparatively higher number than other nearby towns, and suggests a higher rate of settlement for veteran soldiers of the Roman armies stationed in Egypt. ${ }^{4}$

It seems that the site was apparently inhabited continuously and generally prosperously over its lifespan, although it experienced fluctuations in prosperity, and also there were some notable recessions that mirrored difficulties experienced by the Empire at large; as is the case of the plague of AD 165 that had a devastating effect on Karanis, however it managed to revive, but not until the fourth century did the town experience an irreversible decline.

It seems that failure of the canals and increasingly arid climates in the Late Antique period led to the evaporation of Lake Moeris, the central source of irrigation in the Fayum. ${ }^{5}$ Its area shrunk leading to the gradual decline to Karanis and other ancient settlements that depended for its life on the lake. The inhabitants were forced to abandon the site and by the early $6^{\text {th }}$ century the desert had reclaimed Karanis. ${ }^{6}$

\section{The Significance of Karanis:}

As an archaeological site Karanis seems to be somewhat unique among Greco-Roman sites in the region. Although not the largest, it is the best preserved and most extensively excavated town in the

1 Boak A.E. (1955), pp. 156-160. The decrease in the number refers to the late 2nd century after the Antonine plague which significantly depopulates the Roman Empire. For more details on that destructive epidemic see Littman R.J, Littman M.L. (1973), pp. 243-255.

2 Boak A.E. (1926), Geogr. Review, pp. 360-2.

3 Alston R.A. (1995), p. 123.

4 Papyrus preserved a collection of letters to or from soldiers that show forth that Karanis contained many military families. See: Bell H.I. (1952), pp. 185-186. For Karanis as a settlement for soldiers in Ptolemaic and Roman times in General see: unpublished dissertation Abdel Hamid M.M. (2005), pp. 8-12.

5The Birket Qarun, with its surface at $-45 \mathrm{~m}$., below sea level, is the meagre modern remnant remnant of Lake Moeris that was over $75 \mathrm{~m}$ deep and covered more than $2000 \mathrm{~km} 2$ of the Fayum Depression. The present Lake is now, roughly a third of its original size. See Ball J. (1952), pp. 126f; Kozolowski J. K., Ginter, B. (1993), pp. 327-36; Garbrecht G., (1987), p.143-157.

6 Pollard N. (1998), pp. 147-162; Shafei A. (1960), p. 190.

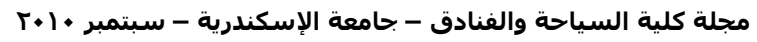


Arsinoite nome (Fig.2). Its significance lies in that the material evidence from excavations, along with many excavated papyri and ostraca, provide much data on all aspects of daily life of non-elites in Egypt from the $3^{\text {rd }}$ century BC to the $6^{\text {th }}$ century AD.

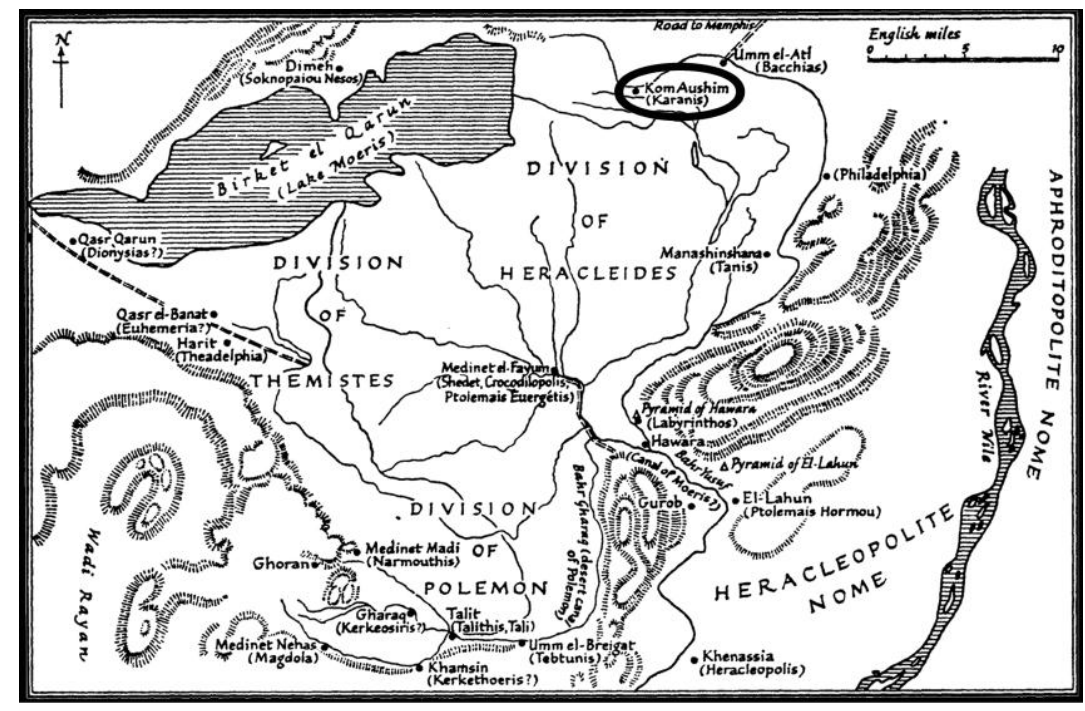

Fig. 2 Karanis and other sites in the Arsinoite Nome (After: Van Minnen P. (1995), p.56.)

Besides, thanks to the excavations of the town, these precious finds can be interpreted in the context of a full array of the material remains in which they were uncovered. Thus it is neither necessary to interpret the archaeological record at Karanis in isolation from any artifactual evidence or written record, nor to interpret finds in isolation from their physical context. Houses, temples, granaries and all that the inhabitants left in them over many generations of occupation lend a tangible reality to the events passed by Karanis in its lifetime.

Moreover, fortunately, the cemetery of the town in its later phase of occupation has partially survived; there are still some funerary artifacts available for study, and many of those are rich with cultural symbolism, waiting to be read.

Thereby, the value of Karanis is not only in providing archaeologists with a documentary history of the people who occupied this Egyptian city between Ptolemaic and Christian times, Karanis also offered a wealth of material for the economist, historian, sociologist, art historian, and linguist. A review of the research resulting from the Karanis excavation does, in fact, provide an excellent overview of what a major excavation offers scholars in many fields. 


\section{Hints on the Excavations:}

The study of Karanis began at the late $19^{\text {th }}$ century when it was explored initially by Flinders Petrie during his rapid survey of the archaeological areas in Fayum. Subsequently B.P Grenfell, A.S Hunt and D.G. Hogarth resumed Petrie's path and set their campaign in 1895 on behalf of Egypt Exploration Fund. ${ }^{1}$ These were excavations only in the sense that they explored the surface of the site with occasional test trenches in areas that seemed particularly promising for the recovery of papyri as the sole purpose of the search and the lack of its presence would mean abandoning the site to search elsewhere. No attempt was made to collect archaeological remains, much less to document them. ${ }^{2}$

Under Francis W. Kelsey the University of Michigan undertook the first comprehensive excavations at Karanis for over a decade from 1924 through 1935. The excavations resulted in the discovery of numerous buildings and papyri, and also huge amounts of artifactual material. They were some of the earliest large-scale excavations with unusually full attention to excavate stratigraphically and to record the proveniences of every found object of artifacts and papyri alike, in addition to the level in which they were unearthed. ${ }^{3}$

Different periods of occupation on the site were tentatively identified by the Michigan team and designated as separate settlement layers with the A-Level being the uppermost, the most recent strata beneath the surface, and thereby identified as the final occupation phase, whereas continuing downwards to strata of B-Level through ELevel below, with E being the oldest. Excavators believed that these levels were persistent over the entirety of the site. ${ }^{4}$ As a matter of fact, fact, the material remains unearthed during these excavations create a complex doc-umentation of life in rural Egypt that spans the Hellenistic, Roman and early Christian periods.

Further excavation of Karanis was carried out under the auspices of the University of Cairo from 1966 through 1975; these excavation uncovered Roman baths, residential structures, coin hoards and papyri. However, perhaps only the tenth of the town's surface area has been excavated, which may represent the downtown area.

1 Petrie W.F. (1892); Grenfell, B. P. et al. (1900).

2 This was admitted by British explorers, stating: "We were in search simply of papyrus, and whenever a house did not contain the peculiar kind of debris among which papyrus was to be expected, we desisted from its exploration". See Grenfell, B.P. et al. (1900), p.38.; Husselman E.M (1971), p.1.

3 Gazda E.K., ed., (1983), pp.1-7.

4 Boak A.E. (1926), JEA, pp. 19-21. 
Unexcavated portions of Karanis were surveyed magnetically by A.G. Hussain around 1983, revealing the presence of still further structures. ${ }^{1}$

\section{The Necropolis of Karanis:}

From Archaeological point of view the necropolis of Karanis is a relatively unknown site, since it was only preserved in the excavators' preliminary reports. A rather terse account of the work was published by Grenfell and Hogarth, the early explorers of the site, but their report provided no evidence that enables us to identify the effective location of the tombs excavated, only stating that they are situated somewhere to the north of the town-sites, on the high ridges which rise at the ancient limit of cultivation. ${ }^{2}$

According to the British researchers there was no true archaeological interest in the tombs albeit for being a potential source of papyri. In their words the graves of the necropolis had been looted, but still return among others, written materials, through which it was possible to attribute the ancient toponym 'Karanis' to Kom Aushim ".... in them we found a number of papyrus fragments, good ornate blue ware, terra-cotta figurines, and many wooden objects, e.g. a little model wagon and a tablet inscribed: ${ }^{3}$

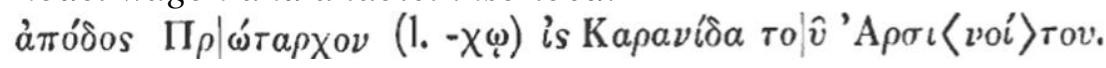

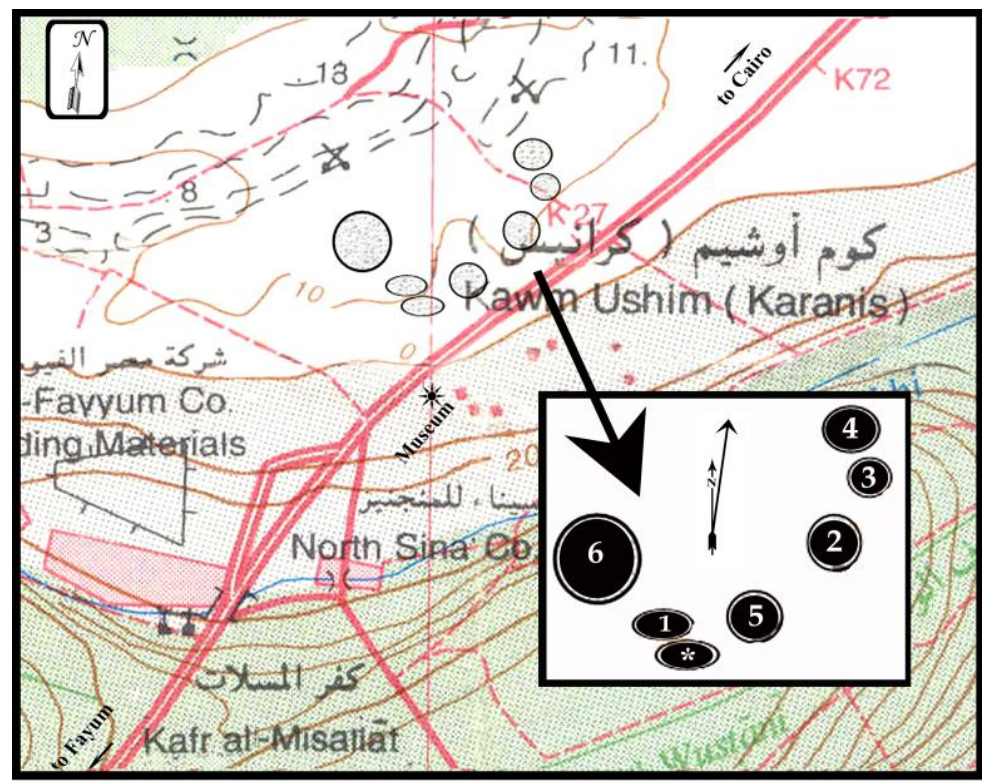

Fig. 3 The Necropolis of Karanis on the E.G.S.A Map (The Author)

[The inset show circles: 1-4 Mounds; 5 Enclosures; 6 Mastaba; $*$ Clandestine]

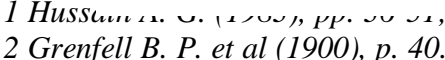

3 Grenfell B. P. et al (1900), p. 41.

$$
\text { مجلة كلية السياحة والفنادق - جامعة الإسكندرية - سبتمبر • + † }
$$


In the later $20^{\text {th }}$ century (between 1989 and 1992) the SCAInspectorate of Fayum Antiquities reported the partial discovery of a badly looted cemetery in the district to the west of the ruins of ancient Karanis on the western side of the desert highway Cairo/ Faiyum (Fig.3). ${ }^{1}$ The work was resumed in the northern portion of the cemetery in the excavation seasons of 2003, 2004 ${ }^{2}$ and $2008 .^{3}$ As previously noted, the data related to these discoveries remain completely unpublished. Therefore Karanis' Record of Objects Books would be useful tools in overcoming this limitation and furnishing the cultural milieu of the site as they often list finds excavated. Furthermore, most of the pottery finds collected during the excavations were deposited in the stores of the museum of Kom Aushim, which would provide further insight into the chronology of the site.

\section{I Reconsidering the Necropolis' Location:}

The aforementioned hints made the precise location of the necropolis disputed, whereas according to Greek burial customs, if the tombs belonged to Ptolemaic age or later; their objective was to bury their dead at any site outside the city, in any direction whether east, south or west; especially that the dead according to the traditions of the Greek were impure and must be buried in the outskirts of the city ${ }^{4}$ as happened in the case of Alexandria being surrounded by "The City of The Dead" as stated by Strabo".

Taking this into account might interpret the location of the graves to the north as mentioned by Grenfell's mission and to the west according to Fayum Inspectorate. But remains the question; if that was the situation, why then such absence of any reference to those tombs uncovered by the British mission? Even that the Fayum Inspectorate credited its team the lead in the discovery of the burials of Karanis' inhabitants, without referring to any previous excavations or making comparisons between what has been uncovered and what was revealed by the British mission, although there are some similarities, as will be described below. In an attempt to answer this inquiry an on-site visit to the necropolis was conducted to verify the accuracy of the location

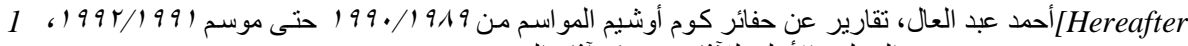

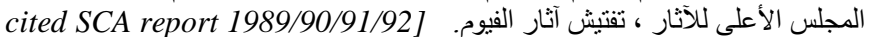

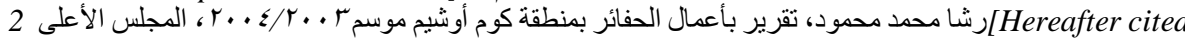

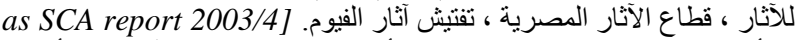

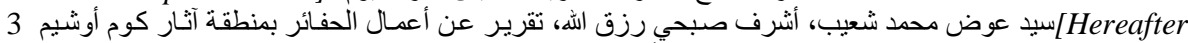

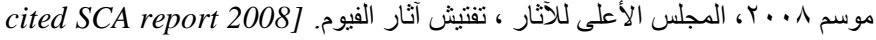

4 Kurtz et al (1971), pp.41, 143.

5 Strabo, XVII, C. 793, 794 
of the necropolis and its features assisted with the available site sketches, the E.G.S.A. map ${ }^{*}$ as well as Google Earth map of the Site (Fig.4).

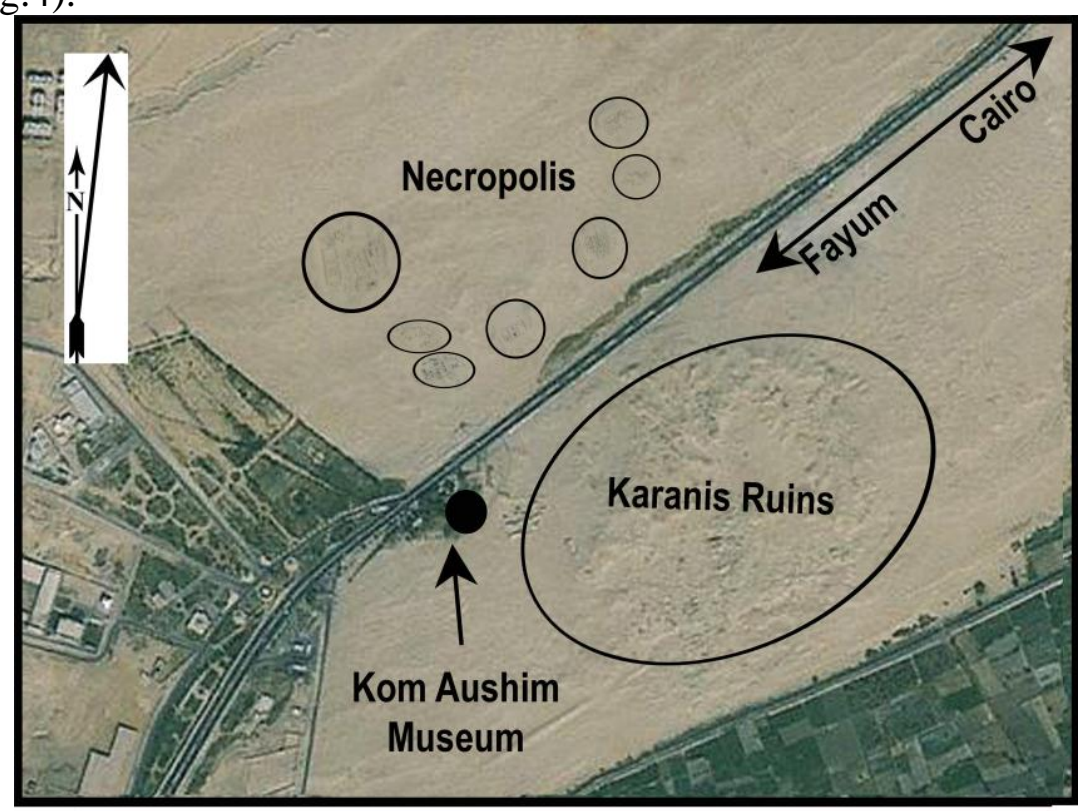

Fig.4 Google Earth Map of Karanis (Author)

The location of the necropolis, according to the reports of the Fayum Inspectorate, was described in relation to the highway running northwards to Cairo. Building on that, the inspectors were inaccurately confused between the left hand-side of the roadway and the west direction. Whereas, noting that the highway route from Cairo to Fayum is headed southwestwards, and that at the point that lies approximately $70 \mathrm{~km}$ far from Cairo it gradually deviates further westwards for a distance of about $4 \mathrm{~km}$ - where the site of Karanis before it gradually turns south to the capital city of Fayum. Herein lies the error resulted in a mislocation of the necropolis to the west instead of the northwest, or metaphorically the north as reported by Grenfell's mission (Fig.5).

One might tends to believe that the earlier features of the necropolis detected by the British researchers, like most other structures of Karanis have suffered dramatically over time from the damage caused by rainfall and erosion from the desert wind, being buried in the course of time and neglect under the sand blown from the remorseless desert. It remained as such until recently, when the

* Egyptian General Survey Authority (1995), Maps of scale 1:50000.

مجلة كلية السياحة والفنادق - جامعة الإسكندرية - سبتمبر • + † 
SCA-Inspectorate of Fayum uncovered a large portion of the sand buried ruins. However, further excavation work might be expected since subsurface stone spotted through Google Earth and to some degree visible to the naked eye outweigh the presence of buried structures.

For further accuracy in locating the necropolis, a preliminary plan of the site has been generated based on the E.G.S.A. map and on information extracted from Google Earth that explicitly pinpoints a GPS location of the site.

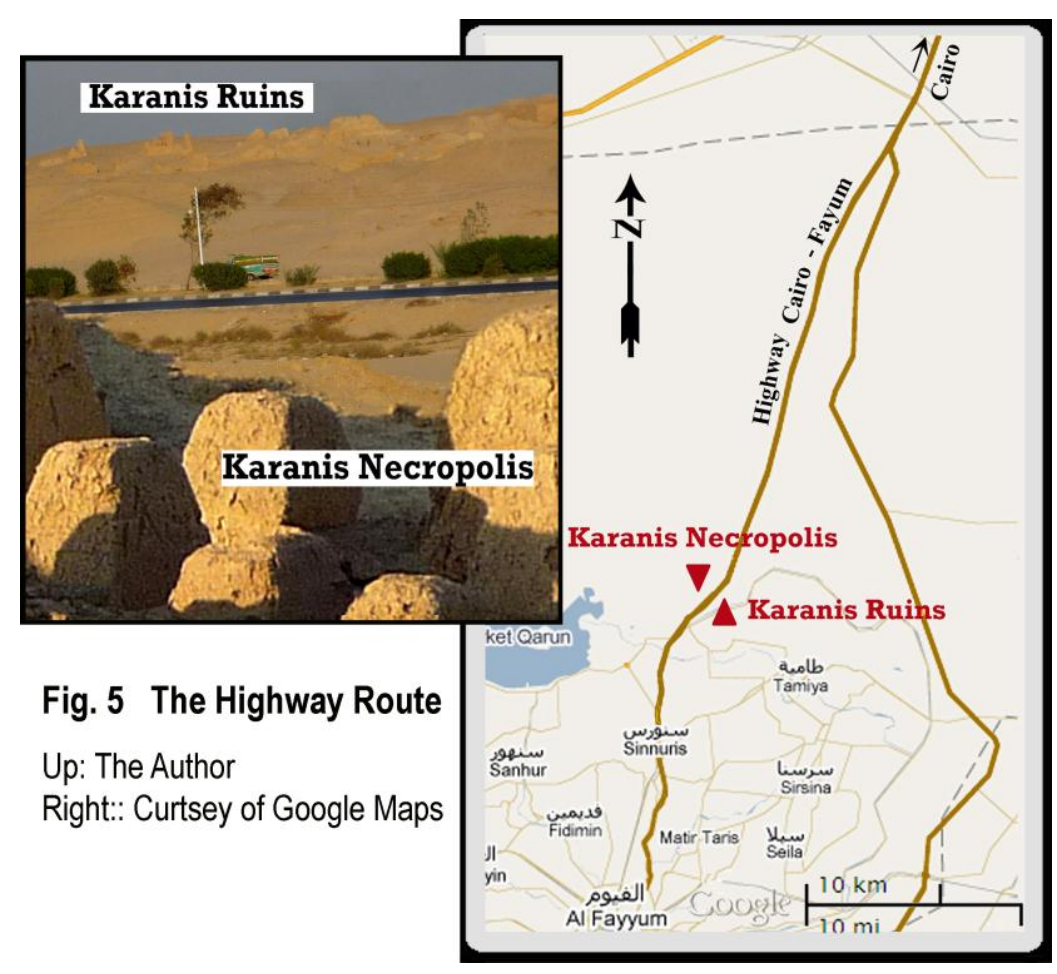

\section{II The General Description:}

The necropolis is assumed to have been the primary burial area for the inhabitants of Karanis. In its current state it occupies an area of about 34 acres $^{1}$ extending breadthways, and is organized into a series of burial mounds randomly scattered that represents the density of interments (circles 1 to 4 on the site map). Other types of graves are also recorded denoting different times of use. The site appears to be the focus of clandestine excavations and other kinds of destructive activities such as a rash of robberies that plundered the graves. Almost none of the tombs were found intact. Besides, surface skeletal remains

1 Calculations used Google maps area calculator tool.

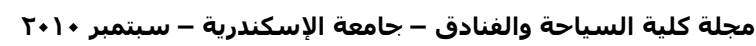


are obviously observed scattered throughout the cemetery's limits (Fig.6).

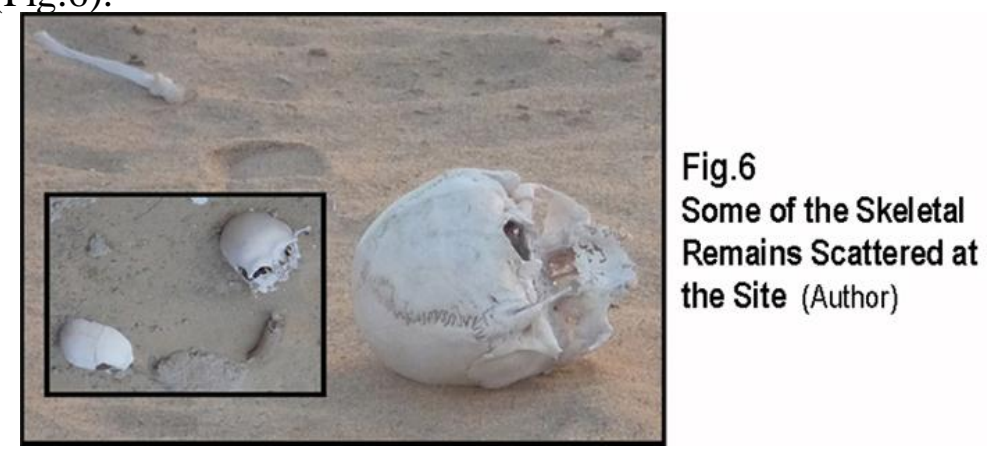

According to Grenfell's mission, three types of tomb are offered: rock-cut shaft tombs, brick tomb enclosures and small brick mastabas. However, not all of them are visible, but remain concealed under the sand waiting for further digs to be completely unearthed. The latter type was rediscovered more accurately when the necropolis was the site of major excavations by Fayum Inspectorate that managed also to expose four burial mounds adding another type of interments to the necropolis (circles 1 to 4 ).

Whereas, during the aforementioned site-visit a personal survey of the necropolis disclosed that the south western section had been subjected to anonymous digging that yielded the fifth type of graves, clandestinely excavated, consisting only of simple pits carved in the ridge which might be considered the oldest pattern in the necropolis.

Chronologically speaking, adopting criteria of stratigraphy used by Michigan $^{1}$, the earliest group of graves would be those cut into the ridge's bedrock, being the lowest datable level discovered so far. From this standpoint, the burial mounds being the uppermost and the most recent strata beneath the surface would thereby be identified as the last cemetery phase and mostly dates to this later period of use in Karanis when the city had a large Coptic population.

\section{II-1 The Pit Graves:}

About 140 meters north of the highway in the southwestern section of the necropolis we came upon a number of test trenches at the foot of burial mound to its south (circle 1), which obviously indicates clandestine probing through the site at some undefined time in the past, which led to the discovery of several pit-graves cut into the bedrock to an average depth of $60 \mathrm{~cm}$. The other dimensions are variable since the pits recognized are of two types; the first are simple rectangular pits of the corpse length or slightly longer (circa $1.9 \mathrm{~m}$ long

1 Boak A.E. (1926), JEA, pp. 19-21.

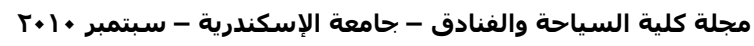


by $65 \mathrm{~cm}$ wide), the other type is roughly anthropoid shape orientated with its head to the east of approximately $2.20 \mathrm{~m}$ in long and its maximum width is $90 \mathrm{~cm}$ at shoulder level (Fig.7).

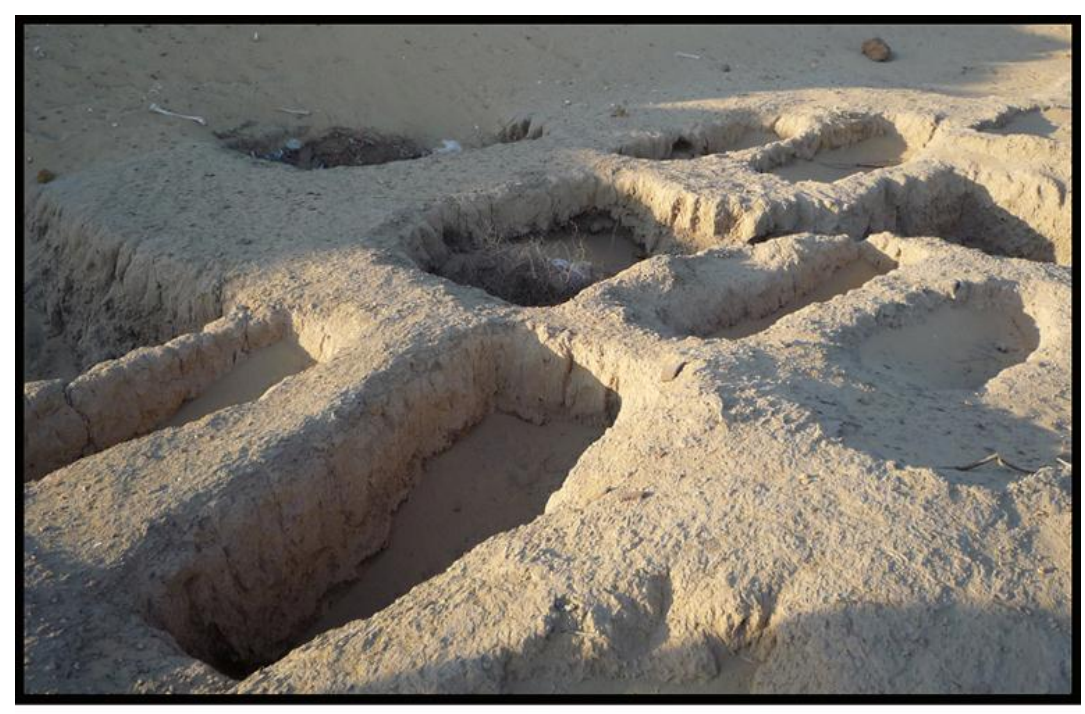

Fig.7 Pit Graves at the foot of the 1st Burial Mound (Author)

All the tombs had been robbed out that no evidence remains to deduce body disposition, or distribution of grave goods, etc. However, only the orientation of the graves could presumably be detected credited to the anthropoid pits that show the graves aligned on an eastwest axis with the head to the east which stands in accordance with Greek burial custom ${ }^{1}$, and in the same time accord with the ancient Egyptian funerary beliefs where the west is deemed as the entrance into the hidden land and the deceased final abode. ${ }^{2}$ Therefore, a person being buried head east would rise facing west, the direction associated with death. In this regard, an early dating of these pits would be suggested as it seems likely for the early Greek settlers who settled at Karanis under the first Ptolemies to adapt the custom of the majority of the inhabitants, namely the Egyptians.

As for the Pit graves, they are all simple pits, without any architectural features and there are no mud-bricks to define the edge of the grave and no superstructures. This kind of tombs was known in ancient Egypt since Predynastic period and continued to serve common classes throughout Egyptian history. It was also common in many parts of the Greek world since the fourth century BC onward. ${ }^{3}$ It

1 Kurtz et al. (1971), pp. 40-43

2 Erman A. (1966), pp. 306f; Perry W.J. (1925), pp. 191-200.

3 Kurtz et al. (1971), pp. 40-43. 
is therefore evident that the tombs of both Egyptian natives and the new settlers living in Graeco-Roman Egypt also share features that tie them to a growing cultural interaction between the two cultures. ${ }^{1}$ Examples of this type are found in the Ptolemaic tombs of Alexandria. Close parallels are also found in tombs of the cemetery of Taposiris Magna $^{2}$ and at Quesna in the Minufiyeh region, which were also dated to the Ptolemaic period. ${ }^{3}$

Moreover, investigations into the origin and cultural influences of burials involving the anthropoid shape in Egypt provided that they were once restricted to the upper classes in Egypt, but since the New Empire, had been extended to the middle class and the poor. ${ }^{4}$ Thenceforth, they appear continually down through the Ptolemaic period up to the late Roman and early Christian times. ${ }^{5}$

In fact, the major influence of Pharaonic deities Isis and Osiris in Greco-Roman culture was a common feature of the Classical Egyptian revival that was expressed in various ways throughout the GraecoRoman period. Some scholars argued that the dead who were entombed in such way were followers of the Osirian cult of the dead, and in their views these anthropoid pit tombs, more likely, belonged to believers in Osiris during the Ptolemaic Epoch. ${ }^{6}$ Some graves of similar type were found at Fagg el-Gamus cemetery that lies about $19 \mathrm{~km}$ to the southeast of Karanis and were considered the earliest interments in the cemetery. ${ }^{7}$ At Kellis, similar pits were dated the end of the Ptolemaic Period. ${ }^{8}$

Concluding, the east-west axial orientation of these graves, with the burials had the head to the east, as well as its being carved in the bedrock, the lowest stratum seems to favor the Ptolemaic dating.

\section{II-2 The Shaft Graves:}

This group of graves is only known through Grenfell's report. Perhaps they remain buried under the sand as the Inspectorate reports are completely devoid of any reference to them. According to Hogarth, they are located behind Karanis and are the earliest group of the tombs they explored, which in their view seem to belong to the late Ptolemaic epoch.

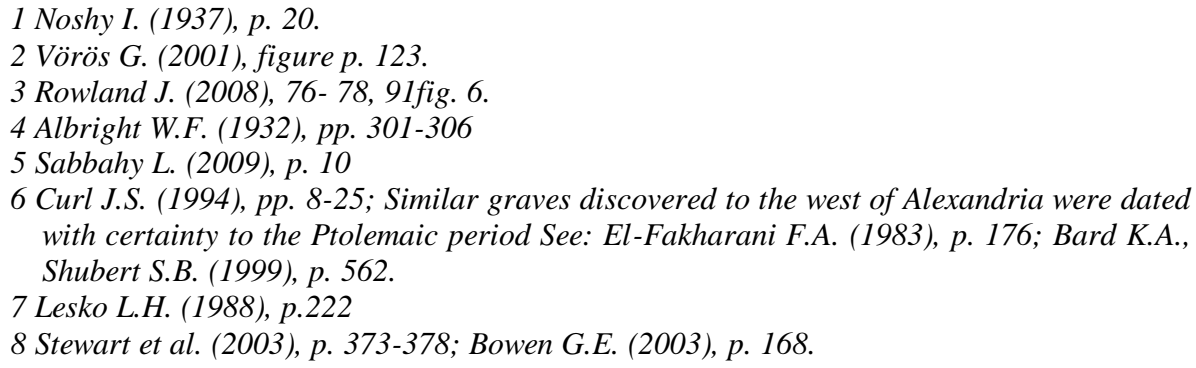


These graves in their type seem to be more elaborate than the aforementioned pits as they are rock-cut graves; each consists of a short shaft or a passage (dromos) in a form of a sloping passage carved into the ridge. The dead were buried in radiating loculi or in a bed scooped out of the rocky floor of the passage itself. It seems that the walls of these type of graves were once plastered and richly ornamented, where a representation of two occupants of a tomb, a man and wife, were found rudely scratched in the soft gypsum." ${ }^{1}$

One of the patterns of interment at Fagg el-Gamus cemetery consists of shafts hewn through the limestone bedrock to varying depths for burial, were dated at their bottom layer burials - based on pottery assessment - to the $1^{\text {st }}$ century B.C of the late Ptolemaic period and continued in use afterwards. ${ }^{2}$ This might stands in conformity with the dating suggested by Grenfell's mission, however, there is no further evidence provided by internal data.

\section{II-3 Mud-Brick Tomb Enclosures:}

Next in order of chronology, according to Hogarth, are a number of mud-brick tomb enclosures that- as he says - were found somewhere that is very close to the mound, but their exact location was not specified. ${ }^{3}$ Quoting Hogarth, "those graves consist of large square or oblong enclosures, apparently houses used as sepulchers. The dead were placed on bed and supplied with fireplaces and all necessaries". On the accounts of papyrus fragments and other finds the British surveyors ranged their dating between the $1^{\text {st }}$ and the $3^{\text {rd }}$ centuries $\mathrm{AD}^{4}$

According to the most recent report of the Fayum Inspectorate ${ }^{5}$, a survey was conducted over large plot of about 113 acres which is a narrow strip of land stretching from south to north, then runs northwards from east to west. Starting through the portion running from the southwest (circle 6 on the site map) to northeast (circle 5), a number of mud-brick funerary enclosures were uncovered that are badly eroded.

Taking into consideration the assumed miscalculations of directions as previously noted, and in reviewing the situation on the ground being compared with photographs taken during the excavation;

\footnotetext{
1 Grenfell B. P. et al (1900), p. 41.

2 Griggs C.W. (1988), pp. 74-84.

3 Grenfell B. P. et al (1900), p. 41.

4 Grenfell B. P. et al (1900), pp. 74-87, 252-56. Among the artifacts found in these graves is the inscribed wooden tablet mentioned above, some papyrus fragments of Chariton's novel (2nd-3rd C. AD) and a lyric poem in Latin also dated (2nd C. AD), as well as an account on a sum of money belonging to a group of soldiers (1st-2nd C. AD).

5 SCA report (2008),pp. 1-2.
} 
thus the area in question would certainly be that include the two circles 5 and 6 on the site-map, but being extending from southeast (circle 5) to northwest (circle 6).

According to the report, the external dimensions of the first Enclosure (circle 5) are $9 \mathrm{~m} \times 7 \mathrm{~m}$, the walls are built directly over the rocky ground and preserved to a maximum of three courses. The second Enclosure is relatively large circa $12 \mathrm{~m} \times 18 \mathrm{~m}$ with a room unearthed at its western side. Worth mentioning that one can see clearly traces of burn on the interior walls of this room, where the grey color of the mud-brick has changed to red. It is said that an amount of ashes up to $50 \mathrm{~cm}$ high and $70 \mathrm{~cm}$ wide was collected. The walls are badly eroded and only preserve remains of its foundations, being built of limestone debris and mud-bricks. ${ }^{1}$

The third Enclosure is partly unearthed (circle 6) of the measures $7 \mathrm{~m} \times 7 \mathrm{~m}$ preserves only the elevation of two or three courses of mudbricks to a height of 25 to $50 \mathrm{~cm}$.

Concluding, it seems obvious that both Hogarth and the Fayum inspectors are talking about the same structures. However, apparently little survives of their super-structures, except for the amount ashes that remained as witness to the fireplaces recorded by the British surveyors. The place has been robbed and completely stripped of its artifacts; therefore it would be more plausible to date these enclosures in conformity with the British mission to the Roman period.

\section{II-4 The Mastaba - Graves:}

In Hogarth description, more mud-brick graves were found that had the appearance of small mastaba very rude in construction, on whose western outer wall was always a little niche for offerings. The deceased were entered without any mummification or adjuncts. In his view, those graves are later than the previous type as their superstructures were found sometimes built within, and sometimes across the walls of the enclosures and in consequence he dated them to the later Roman period at Karanis. ${ }^{2}$

Such graves were briefly touched upon in the excavation report of the Fayum Inspectorate mentioning that part of the necropolis (marked as circle 6 on the site map) is dominated by the remains of mud-brick enclosures adjacent to some graves identified by their mud-brick superstructures, preserved to a height of 50 to $75 \mathrm{~cm}$, being characteristically within the funerary contexts of late Roman period (Fig.8). ${ }^{3}$

1 SCA report (2008), p. 2, figs: 1,2

2 Grenfell B. P. et al (1900), p. 42.

3 SCA report (2008), p. 2, figs: 3,4

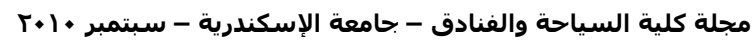




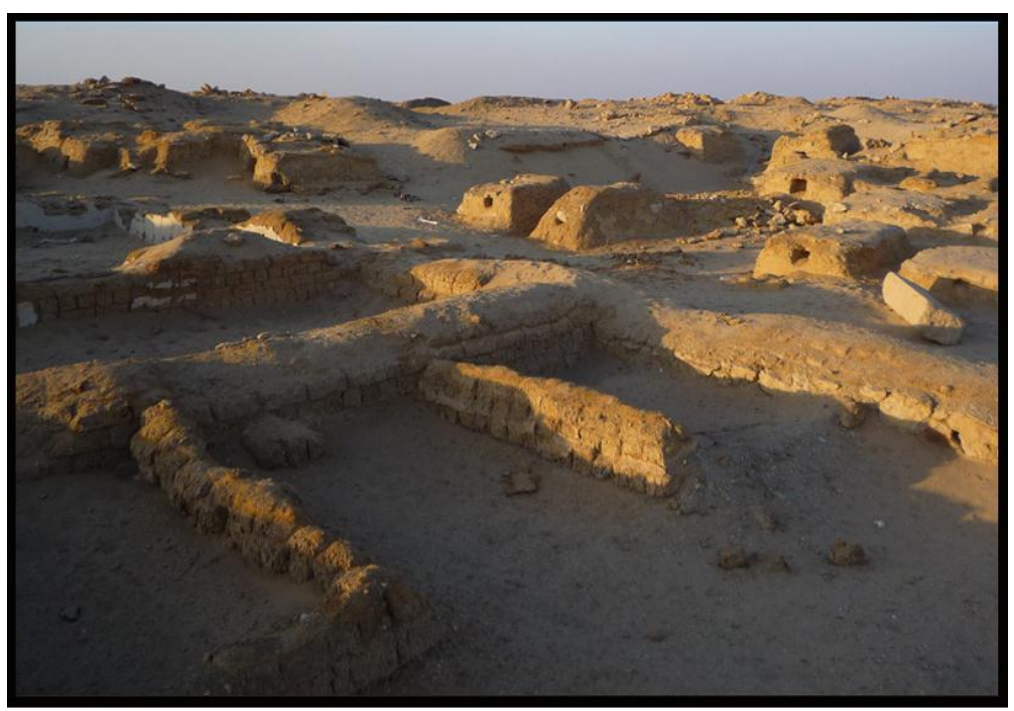

Fig.8 Mastaba Graves and the adjacent Enclosure (Author)

Personal scouring of the site for further details contributed to the visibility of a once more clandestine or unauthorized excavation that was conducted after the termination of the Inspectorate's mission, as there is a difference between the original sketch plan, created by the Inspectorate architects, and the current situation on the ground (Fig.9). ${ }^{1}$ There are more mastabas unearthed all constructed of mud brick and covered by a thick layer of mud plaster. Apparently, all of the superstructures have suffered the effects of erosion and it is not possible to determine their original height, but their height ranges from 30 to $75 \mathrm{~cm}$ above the current floor level.

Adjacent to the mastaba graves is a rectangular enclosure of three consecutive rooms each gives access to the other, being orientated northwards. The walls of the enclosure in their best preserved portion rise to a height of 25 to $50 \mathrm{~cm}$. The interior surfaces of the walls were covered with a coarse white gypsum plaster. A wooden door threshold is found between the two rear rooms in the enclosure indicates that there may have been a door. Surface skeletal material scattered throughout the enclosures (Fig.10).

1 Differences are marked on the sketch plan with strokes and dark black squares.

مجلة كلية السياحة والفنادق - جامعة الإسكندرية - سبتمبر • + † 


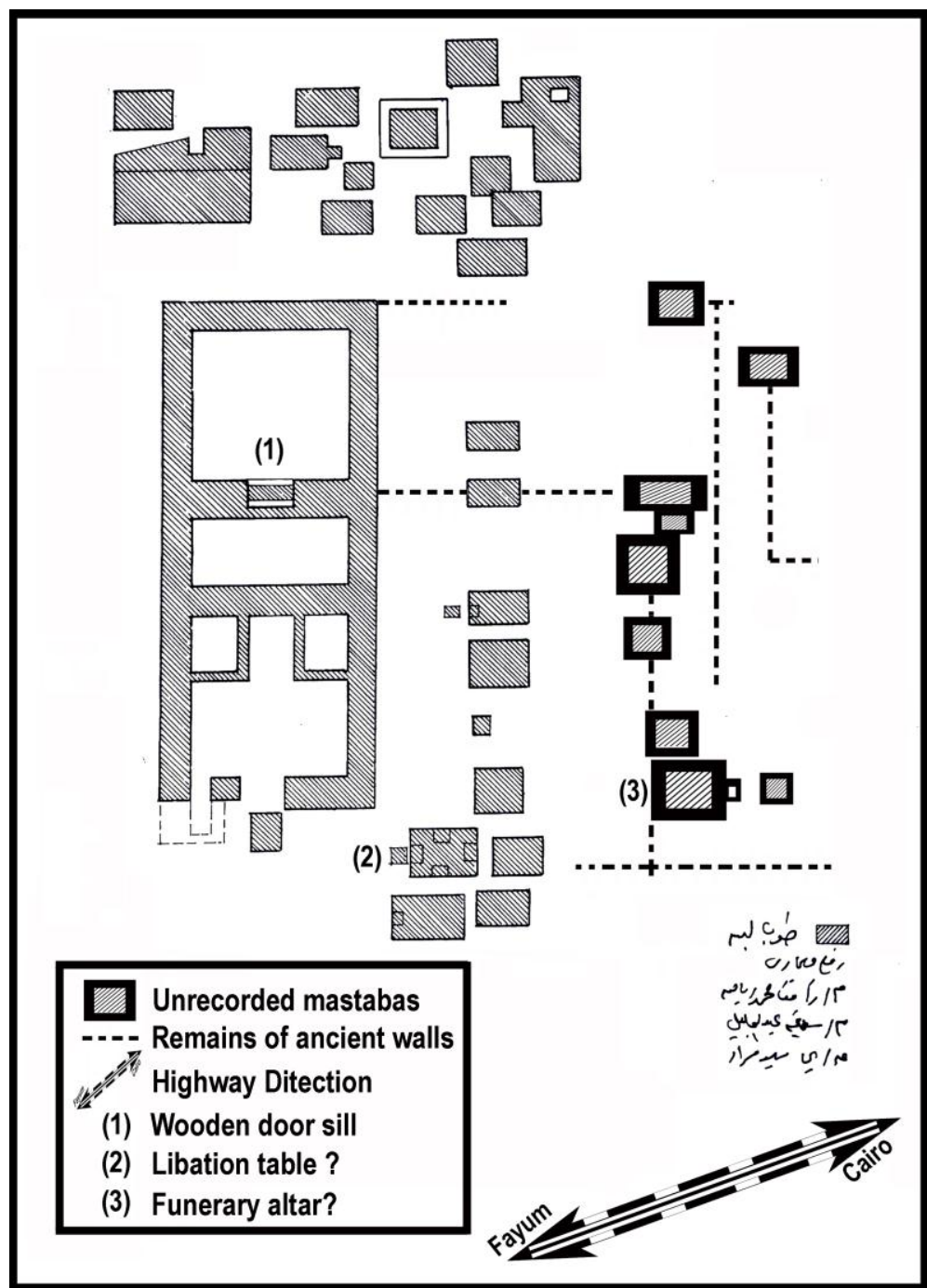

Fig.9 Sketch Plan of the Mastaba Graves and the Adjacent Enclosure (After SCA report (2008)- meodified by the author on the basis of personal observations at the site. Additions are shown as described in the inset)

It is worth noting what Hogarth said before, that several mastabas intersect the walls of the enclosures whose delineations are occasionally observed beneath and around the graves. Such overlapping might denote a later phase of the cemetery use and that the enclosures might predates the mastaba graves.

Furthermore, it is noticeable that the portion at the southeast has a peculiar nature:

- Here all mastabas are coated with a thick layer of reddish mortar formed with a powder mix of grounded burnt brick that was known 
since the Roman times in constructions susceptible to moisture or water. ${ }^{1}$

- Moreover, one of the superstructures is a low rectangular podium with four square recesses, one in the middle of each side, and is preceded by a drain carved in the ground. The podium and the drain had the same hydraulic reddish mortar (Fig.11). Most probably this structure represents a libation table for liquid offerings particularly that the remains of what seems to be a square funerary altar for sacrifices is situated close by.

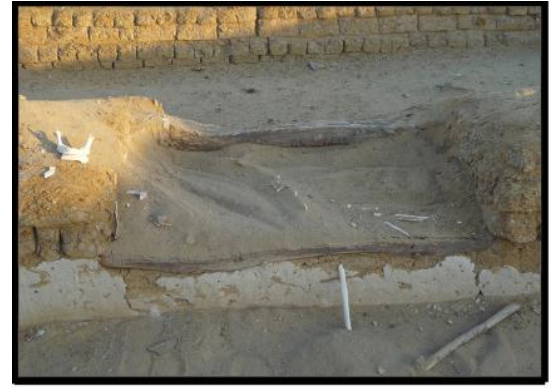

Fig. 10 Wooden door sill (Author) A Jawbone is seen on the left side

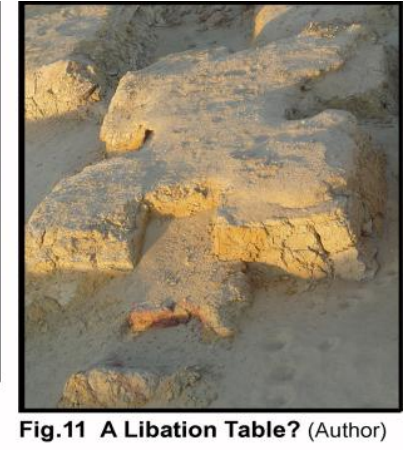

- The altar is a four-sided mass of mud-brickwork and covered with reddish plaster, the remains of which are still observed. It is drained into a small square basin in the ground, on which is seen some traces of ashes that might indicate that incense was sometimes burnt on it (Fig.12).

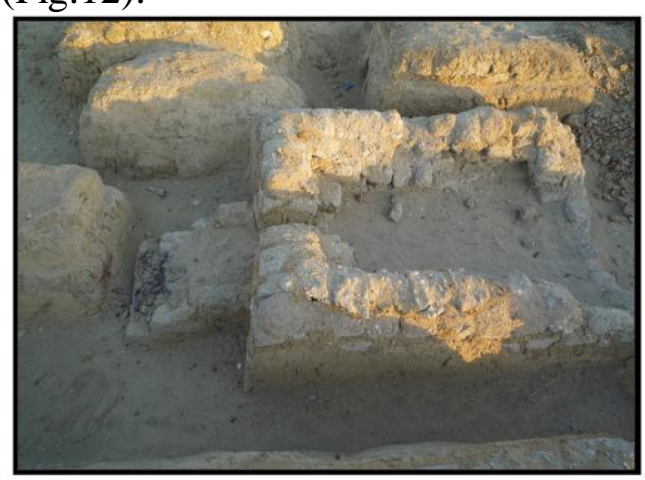

Fig. 12 A Funerary Altar? (Author)

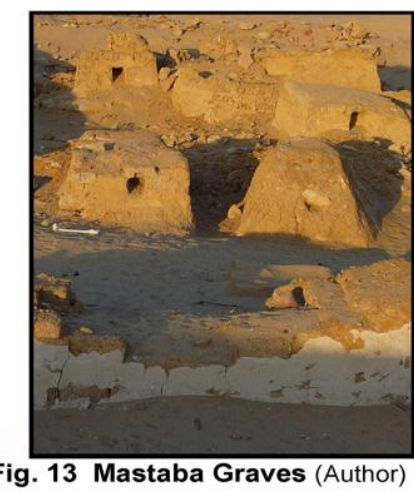

with square cavities

All these characteristics show forth that here the rituals of pouring libations and offering sacrifice in memory of those who have died were practiced.

1 In his "De Architectura", V.10; VI.6.7; VII.4.3.1, Vitruvius talk about walls covered with burnt clay to prevent seepage, this hydraulic reddish mortar continued in use with some carelessness during the Byzantine. 
Another remarkable characteristic is that the majority of the mastabas feature a little square cavity in their western façade.

Such cavities were based on a strong pagan tradition of long standing (Fig.13); offering niches were known in ancient Egyptian mastabas ${ }^{1}$ - mostly on the east side - where the living could make offerings and burn incense with the object that the incense burned before the tomb might enter to where the deceased was buried, in the belief that his spirit would rejoice at its odour and enjoy its perfume, especially that for the Egyptians incense was a potent tool for restoring life and offering the dead a mode of transcendence from earth to the heavens. ${ }^{2}$

Such rectangular opening is also found in several funerary stelae with the purpose of bestowing the deceased a passage towards the sky and the direct communication with the outer world. In this regard, Badawy has already suggested that the openings in such stelae were virtually false doors which provided the $b a$ or soul of the deceased with a magical means of leaving and entering the burial-chamber at will. The $b a$ of the deceased was the particular spirit-form of a person that enjoyed freedom of movement. ${ }^{3}$ In some Stelae this aperture is provided with the Egyptians amulet of life 'ankh', which was explained by scholars as if signifying the real provision facilitating the resurrection of the dead. In this concern, this aperture might conceivably be connected with the epithet bi-ankh, 'living soul', and that the facility of movement (egress and ingress) would be the mark of having 'life' or resurrect. ${ }^{4}$

It seems that this concept surfaces again among early believers of Christianity. ${ }^{5}$ Large number of the Coptic funerary stelae in the Coptic museum has a tiny square aperture penetrating to the back of the stela. ${ }^{6}$ Concerning the doctrines of Christianity, this aperture has no function whatsoever except being adopted from ancient Egyptian symbolism concerning offering and censing before the tomb. ${ }^{7}$

1 Watson P.J. (1987),pp. 34ff.; Emery W.B. (1961), p. 94; Vandier J. (1952), p. 695-6, fig. 457 n. 132.

2 Blackman A.M. (1912), pp. 69-75.

3 Badawy A. (1953), pp. 129ff., 137-139

4 Kitchen K. A. (Dec., 1961)

5 Pelsmaekers J. (1991), p.2150; Kamel I. (1987), p. 13; Kamil J. (1983), p.61; Habib R. (1967), pp. 87ff.

6 Examples of such stelae with axial aperture: Coptic museum, Inv. Nos. 320, 8019, 8593, $8598,8615,8629,8663,8670$, and 8673.

7 Kamil J. (2002), p. 148; Gero S. (January-April 1977), pp.74-80.

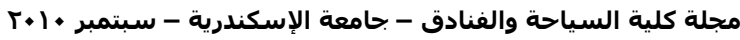


Censing in the Coptic liturgy reflects the themes of resurrection and fertility associated with ancient fumigations. ${ }^{1}$ It is known that the influence of the Pharaonic legacy, especially in religion, survived into the Christian tradition. The theme of Isis nursing Horus would find its way into the iconography of Mary and Jesus; the resurrection of Osiris came to be echoed in the resurrection of Jesus; and the influence of the hieroglyphic ankh can be seen in the form of the Christian cross "crux ansata". ${ }^{2}$

The early Christian period (ca. AD 100-450) in Egypt presents a confusion of beliefs and practices, a time wherein ancient and new ways of life mixed, producing an amalgam of beliefs and practices, particularly in the treatment of the dead and creation of the funerary landscape.

Taking the whole account into consideration, those interred in the mastaba graves would presumably be identified as belonging to the early Christian community at Karanis. In its turn, this might interpret the position of the niche on the western façade of the mastaba instead of the east as going in accordance with early Christian beliefs that remarkably shifted the burial direction towards west-east orientations. A person buried with the feet to the east and heads to the west in order to rise facing the direction from which the resurrected Christ is supposed to approach on Judgment Day. ${ }^{4}$

\section{II-5 The Four Burial-Mounds:}

Four burial mounds are uniquely recognizable at the necropolis. According to the excavation reports, they are not natural landscape feature (Fig.14). ${ }^{5}$ They are artificial mounds formed of earth, rubble, debris and skeletal remains and ranging in their height from 4 to $10 \mathrm{~m}$. above the ground surface. ${ }^{6}$ (circles $1-4$ on the site-map).

1 Incense ritually helps restore life to the dead Christ on Easter morning after the clergy "inters" an icon of the Lord beneath the church altar. The priest incenses the altar and then "resurrects" the icon from its liturgical tomb to the sound of a triumphant anthem. See: Butler A.J. (2004), pp. 2.351-53.

2 Rice M. (1997), p. 197.

3 Frankfurter D. (1998); Bowen G.E. (2003), p. 169

4 Davies J. (1999), p. 199.

5 SCA report 1990/91

6 SCA reports 1989/90; 1990/91. 


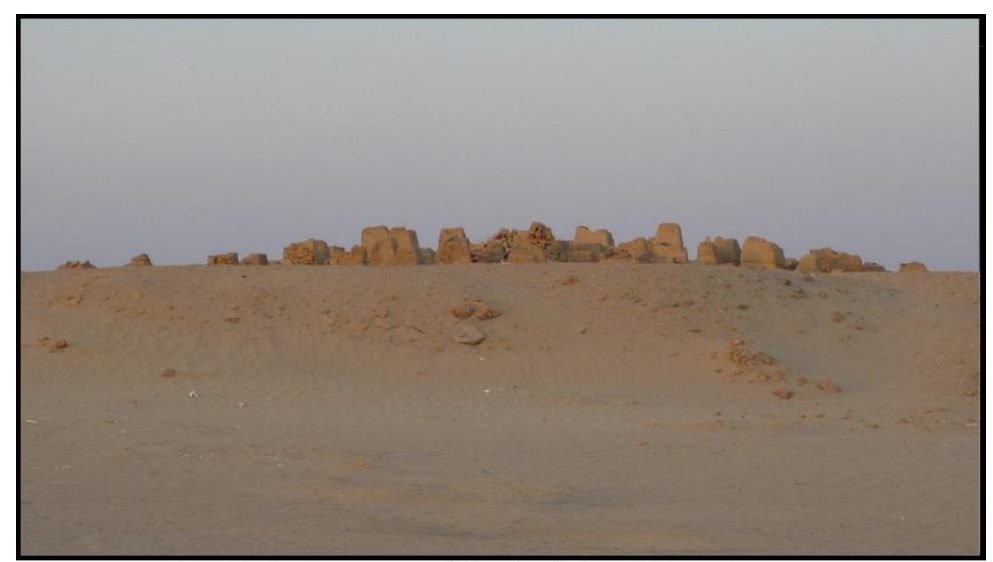

Fig. 14 An Overview of the 2nd Burial Mound (Author)

Excavations revealed that the interments within these mounds were expanded vertically as being used for successive burials. ${ }^{1}$ In general, the interments are fairly poor, consisting of simple pits of variable dimensions. The latest additions were frequently placed on top of previous inhumations; accumulating sand (and in some instances mud-bricks) continually covered burials, thereby providing new surfaces for interment. However, the burials are not evenly spaced in depth, but sometimes one touches the next, and at other times debris, sand and rubble separate the burial layers. In view of the excavators such subsequent inhumations, indicating that the burials were emplaced at different times, with the lowest layer being the earliest. $^{2}$

\section{Burial Practices Observed in the Mounds:}

About 175 burials $^{3}$ were recovered within these mounds. According to the excavation reports all depositions within the burial mounds are placed in direct contact with the sand. The bodies were not placed in coffins, and generally have no protection except for their wrappings, which might have partially contributed to their mutilation, and perhaps took part in such remarkably widespread phenomenon of disarticulated and disturbed human remains that were recovered within the mounds during excavations. ${ }^{4}$

It is worthy here to note that according to the excavation reports all inhumations in the mounds are placed as customary in the necropolis on an east-west axis with slight deviations; but the most

3100 interments were recovered in the 1 st mound, 15 in the 2 nd mound, 30 in the $3 \mathrm{rd}$ mound, and 30 on the 4th mound. SCA reports from 1989/90 till 1991/1992.

4 These observations recurred in all SCA reports.

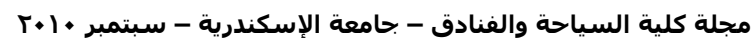


striking feature is that it is commonly within the mounds that burials from upper layers were placed with the feet at the east and head at the west, while the bottom layer burials, however, almost always reverse the direction, having the head to the east and feet to the west. Such marked distinction in burial direction between the upper and lower burial layers within the same mound would certainly refer to a significant change of technique in burial ritual activities of Karanis inhabitants, which can best be accounted for a major cultural upheaval in the area that led to the difference in the beliefs about the afterlife; and thus would certainly point to early Christian influences.

Evidently, this remarkable shift in burial direction between preChristian and Christian burial orientation is best exemplified by the shaft burials at the aforementioned Fagg el-Gamus cemetery in the Fayum region where there are as many as five burials from near the surface to the bottom of the shafts (Fig. 15). Only burials from the bottom layer of the shaft were 'head east', while a consistency in burial techniques 'head west' from that level to the surface level of the cemetery. Assessment of the pottery associated with these burials confirmed that it was right around the end of the first century or the early part of the second century $\mathrm{AD}$ that the burial direction started changing, and that the cultural change which occurred in this area was dominant for at least the next six or seven centuries (terminus post quem of the surface level according to pottery is the $8^{\text {th }}$ century AD). Scholars believe the best explanation for such a remarkable shift in burial direction is the arrival and widespread adoption of Christianity; for them it also accords with the fact that Christianity became the dominant religion in Egypt for the succeeding centuries. ${ }^{1}$

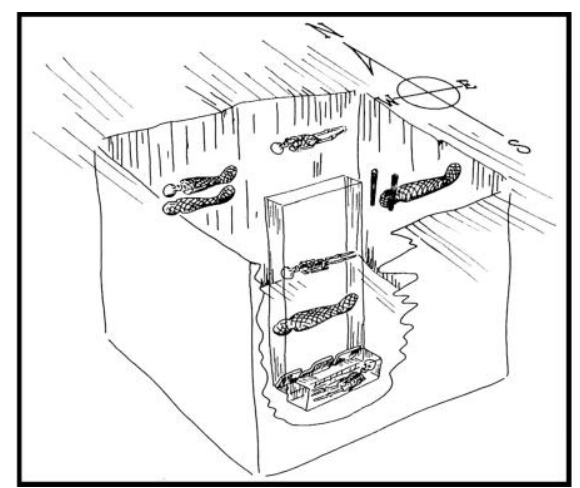

Fig. 15 Sketch Illustrating Burial Patterns in Shaft Burials at Fagg El-Gamus Cemetery (After, Griggs C.W. (1988), fig.2)

Further evidence of early Christian funerary practices in the mounds comes from the excavation reports concerning a number of

1 Griggs C.W. (1988), pp. 74-84, fig.2.

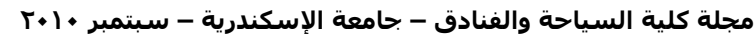


undisturbed burials that were found during the 2004 field season beneath the surface layer. They were lying down in an extended position on its back, being shrouded in a coarse linen bandage that emulates the traditional practice of mummification. ${ }^{1}$ By comparison, this is typical of early Christian burial practices ${ }^{2}$ that are consistent with those found at other Christian sites in Egypt: bodies lying in an extended and supine position with their head to the west. The hands were to the sides or over the pelvic region, their feet placed side by side or crossed, and almost no goods associated with them. ${ }^{3}$ In consequence, those interred in such manner would be identified as belonging to the Christian community at Karanis.

Further evidence is adduced from the survey report of Cairo University mission, which, though has yielded scant information about the cemetery but a mention of a discovered part of the wrappings of a deceased decorated with a cross, would support the supposition that some of the graves have been used for the burial of the early Christians. ${ }^{4}$

As for the report reference of bodies that were typically wrapped in linen shrouds and bound by linen cords or bandages, these are curious survivals of ancient Egyptian mummification practice among the early members of Christian communities. Attempts at mummification have, however, been recorded in the cemetery of the Nahiya monastery at Abu Roash ${ }^{5}$, and at Antinoopolis. ${ }^{6}$ The fact that the Christians of Egypt did not prohibit the preservation of the body after death can be seen in the attitude of St. Anthony, father of the monks of the Nitrian desert during third-fourth century $\mathrm{AD}^{7}$, who instructed his followers not to allow his body to be taken to Egypt after his death except to be embalmed, citing: 'at the resurrection I shall receive it from the Saviour incorruptible'.

1 SCA report 2003/2004

2 Davies J. (1999), p. 199. Davies in his description relied upon the The Didascalia Apostolorum, composed in Greek during the third century in Syria and translated into Latin. "...the body was washed, anointed and sometimes embalmed; it was then carried to the grave where it was buried with a Eucharist. The grave was aligned on an east-west axis and the body placed directly onto the floor of the pit, face upward, with the feet to the east in order to rise facing the Son of Man on the day of resurrection..."

3 Bowen G.E. (2003). pp. 168-71.

4 El-Nassery S.A. (1979), p. 121.

5 Daressy G. (19I7), pp. 274-6

6 Bowen G.E. (2003), p. 169

7 Walters C.C. (1974),, 231.

8 Budge E.W. (1987), p. 214. He published the Greek text from [Life of Antony by Athanasius. (J. P. Migne, Patrologia Graeca 26, col.972.)]

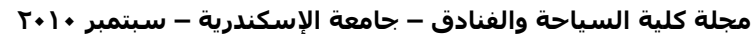




\section{The Grave Markers atop the Mounds:}

Over 100 mud-brick grave markers have been discovered on top of the mounds, and these are the most peculiar feature of the necropolis ${ }^{1}$ (Fig.16); It is, at least according to current knowledge, of a unique type, unknown neither in the Fayum, nor in any other region in Egypt; being constructed of a truncated square pyramid shape. It seems that the grave marker was first outlined with a course of mud bricks which was then filled in with rubble or debris. Only a few cases contained a solid mud-brick core. ${ }^{2}$
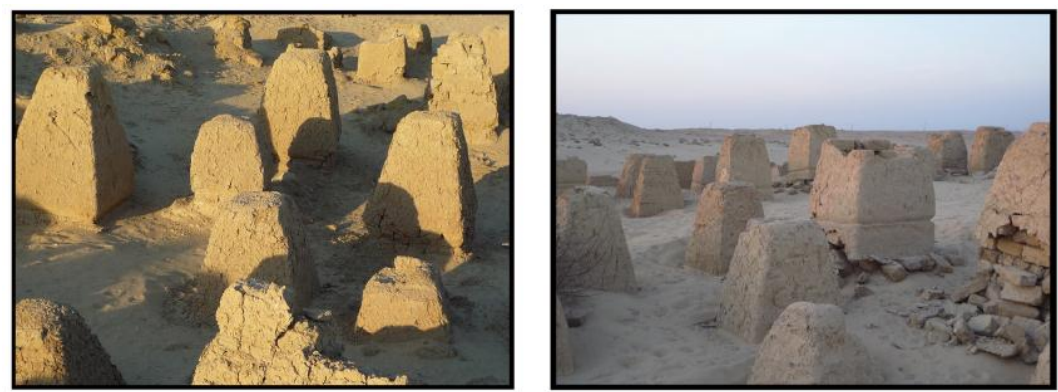

Fig. 16 Details of the Grave Markers atop the Mounds (Author)

Grave markers were then plastered with clay and often impressed with inscriptions, probably of cryptographic character, in which the iconographic pagan tradition and the new Christian figurative language mix. Among the inscribed grave markers some show both the ankh-shaped cross "crux ansata" flanked by the first and last letters of the Greek alphabet $\mathbf{A}$ and $\boldsymbol{\omega}$ in an early form of what was to become the monogram of Jesus Christ symbolizing him as the creator and will be the judge at the end of the world for, in the Book of Revelation 1:8, He said: "I am the Alpha and the Omega, the First and the Last, the Beginning and the End." ${ }^{3}$ This proved beyond doubt that the graves of surface layer would belong to the later period of use in Karanis when the city had a large Coptic population (Fig. 17).

The other grave markers have Coptic inscriptions impressed into the plaster, but almost completely damaged and their reconstruction is impossible. In all only 16 texts could be recorded, mostly fragmentary. As shown in the table below, all texts appear to be simple names or a short prayer as assumed from the remainder of inscriptions.

115 grave markers are reported on the 2 nd mound, 8 on the $3 r d$ mound, and 78 on the 4 th mound. SCA reports from 1989/90 till 1991/1992. In addition to the discovery of some undefined number of grave markers during the excavation season 2003/2004.

2 SCA report 1990/91

3 Francia L. Del. (1991), pp. 2160-2163; Kamel I. (1987), p. 12,16f; Habib R. (1967), p 87. 


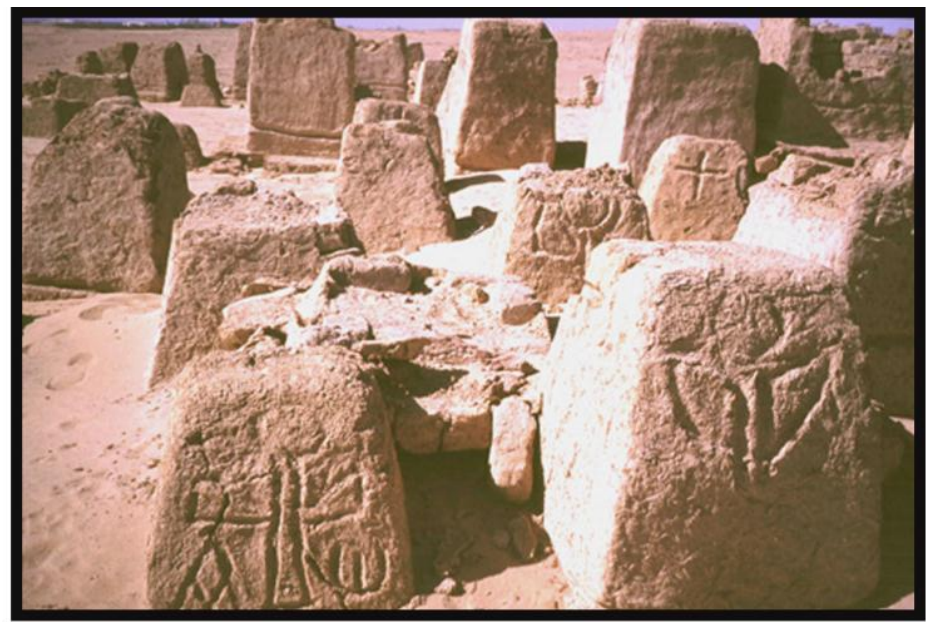

Fig. 17 Details of the Grave Markers atop the Mounds (Author)

\section{The Material Evidence From the Mounds:}

Excavations at the burial mounds led to the discovery and collection of a considerable body of material evidence, complete or fragmentary, that belong to different categories of evidence, such as pottery vessels, lamps, wood and metal objects, dull glass jewels, and items made of ivory. All were uncovered from the upper layers and near the surface. ${ }^{1}$

A key part within the course of this investigation has been devoted to the study of 16 complete pottery vessels recovered from archaeological excavations and now in the stores of Kom Aushim museum, which showed variety of types and functions, being identifiable as Late Roman/Early Christian period; particularly to the time between $5^{\text {th }}$ and $7^{\text {th }}$ century $\mathrm{AD} .^{2}$ Such dating would provide evidence of the continuation of life at Karanis well beyond the limit of the fourth and fifth centuries, until not long before the time considered of final abandonment of the site. ${ }^{3}$ Unfortunately, this paper does not allow for an exhaustive study of artifacts; nevertheless a brief description of them has been catalogued below as well as a summery of the pottery vessels' report.

1The artifacts collected in the excavations of the necropolis were deposited in the stores of Kom Aushim museum and the data related to them were recorded in the Karanis Record of Objects and were not published or studied before.

2Vessels were examined by Mr. Ashraf El-Sonussi, curator of Kom Aushim museum, to whome I am indebted as without whose co-operation as a specialist, the report included below would never been accomplished.

3 Geremek, p. 6, note 6 summarized the latest dated evidence from Karanis. See bellow: "Issues of Chronology"

مجلة كلية السياحة والفنادق - جامعة الإسكندرية - سبتمبر •l+ 


\section{Issues of Chronology:}

Boak in his discussion of the history of the end of the Roman Fayum, stressed the role of the decaying irrigation system in the abandonment of towns on the edge of the Fayum between the $3^{\text {rd }}-5^{\text {th }}$ centuries $\mathrm{AD} .{ }^{1}$ This dating has long been accepted by scholars until recently when a few studies have reevaluated the evidence supporting this chronology. In his study of Late Roman ceramic forms from Karanis, Nigel Pollard has demonstrated that the town was occupied until the early $6^{\text {th }}$ century AD. ${ }^{2}$

Moreover, re-evaluation of the references in Byzantine and early Arabic papyri for towns on the eastern edge of the Fayum has shown that some were still occupied as late as the $8^{\text {th }}$ century AD. ${ }^{3}$ In this respect one would anticipate that Karanis lived part of its lifetime in the shadow of Christianity, even though the archaeological evidences from the settlement give the possibility that it remained a polytheist town during the early Byzantine centuries. ${ }^{4}$

Worth mentioning that documentary evidence of Egyptian monasticism, though sparse, shows that Christianity began in the early centuries among the inhabitants of Karanis. The earliest known use of the term "monk" $\left(\mu \circ{ }^{\prime} \xi_{o}{ }^{\prime} \varphi\right)$ is a papyrus from the archive of Aurelius Isadorus, a citizen of Karanis, in the last decades of the third and the first decades of the fourth century. It is dated to $324 \mathrm{AD}$ and is considered the earliest reference so far known to the "monk" as the "deacon" ( $\left.\delta \boldsymbol{\alpha}^{\prime} \boldsymbol{\kappa} \boldsymbol{\nu} \boldsymbol{\varphi} \varphi\right)$ as recognized figures in society. ${ }^{5}$

Various documents of the same archive also mentioned several people in Christian names like Petros father of Polion in a document (250 AD), Johannes and Paulos (290-300 AD), who were rich persons and they had Acres of lands ${ }^{6}$

Further proof that Karanis had a sizeable Christian community is a Copenhagen papyrus dated to 15 May 439 (P.Haun.III58) showed Karanis, now a Christian village with a clergy of twelve priests and five deacons. ${ }^{7}$ This prompts scholars to believe that Karanis during the

1 Boak, A. E. (1926), Geogr. Review, pp. 353-364.

2 Pollard, N. (1998), pp. 147-62; For a summary of the earlier scholarship see P. van Minnen (1995) 41-56.

3 Keenan J. G. (2005), pp. 211f; id. (2003), pp. 119-140.

4 There is a great deal of evidence for continued non-Christian religious activity, much of it combining the various aspects of the town's culturally mixed population. Boak A.E. (1926), pp. 19-21.

5 Judge E.A. (1977), pp. 72-89.

6 Van Haelst J. (1970), p.498; Boak A.E., Youtie H.C. (1960), p.377f - n.2, p.315 - n.3.

7 Keenan J. G. (2003), 126; Pollard N. (1998), p. 161; Rea J. (1993), p. 89.

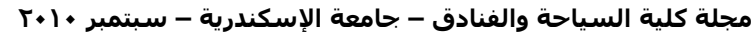


the fifth century, with seventeen clergy, had either managed a revival or presented the legal authority of local clergy. ${ }^{1}$

Given these concerns, the necropolis of Karanis would be of particular interest to historians and archaeologists of early Christian period for this is where much of the archaeological evidence for the transition to Christianity is found. It provides an excellent opportunity to explore the mortuary treatment, particularly under the shifting ideological beliefs and practices from paganism to early Christianity in Egypt.

Knowing that the burial mounds represent the majority of interment - at least so far discovered - thus it is now known that the necropolis, as far as possible, in its majority belonged to and was used by early Christians, who were undetectable in the archaeological record until at least the mid-third century. As there was no prohibition on Christians and pagans being buried within the same tombs or cemeteries $^{2}$, the practice was continued by some Christians beyond the fourth century. ${ }^{3}$ Many who adopted the new religion held an amalgam amalgam of beliefs and practices. The persistence of ancient Egyptian symbolism in early Christian art is very much accepted among scholars, especially that during this early period ${ }^{4}$, the Copts had no right to declare their Christianity, or to perform publicly their religious duties and rites, so that they adopted mixed iconography of both Christian and pagan elements and styles as seen in the adaptation of the ankh, the hieroglyphic symbol for life to the Christian crux ansata. $^{5}$ This tendency differed from the second half of the $5^{\text {th }}$ century century $\mathrm{AD}$ up to the Arab conquest by the beginning of the $7^{\text {th }}$ century $\mathrm{AD}$ as it showed gradual absence of the pagan subjects in contrast to the dominating Christian or Christianized neutral motifs. But the purely Christian nature did not become common until the seventh century. ${ }^{6}$

By the same token, at some undetermined point in time Christians made a conscious effort to adopt a distinctive mode of burial from that of their pagan contemporaries. Separate cemeteries for Christians, therefore, should not be expected prior to the late third century. Bowen in her suggestion of a period of use of the Christian cemetery at Kellis determined that the change in burial practices can only be expected with the adoption of doctrinal developments promoted by the

1 Van Minnen P. (1995), p.51; Bagnall R.S. (1993), p. 138.

2 Johnson M. J. (1999), p.42.

3 Hauser W. (1932), pp. 44-50; Thomas T.K. (2000), p.34; Venit M.S. (2002), pp. 181-6.

4 Morenz S. (1994), pp.256ff; Kamil J. (1983), pp.23ff

5 Bourguet P. Du. (1964), pp. 32, 36, 42.

6 Wilson D.M. (1991), p. 87; Severin H.G. (1991), p.2117.

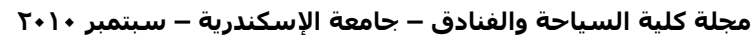


authorities in Alexandria during the Little Peace of the Church from the third quarter of the third century. ${ }^{1}$

In fact, to approach a firm chronology of the necropolis is debatable particularly with the lack of identified pagan inhumations or decisive pagan artifacts. A large scale, town-wide study should still illuminate distinct patterns. The investigation so far indicates that the suggested period of use of the necropolis would range between the late Ptolemaic or early Roman period to the early $8^{\text {th }}$ century at most with the density of Christian interments in the burial mounds.

\section{Notes on Orientation:}

It is observed throughout the necropolis that all graves are aligned on an east-west axis with minor deviations, either for pagan eastern head position or for Christian western head orientation. One of the oldest archaeological questions is whether the orientation of the graves is based on the point at which the sun rises on the day of burial. Generally, it seems to be the working out of the solar analogy on the one hand in death at sunset, on the other in new life at sunrise, that has produced two contrasted rules of burial which agree in placing the dead in the sun's path, the line of east and west. ${ }^{2}$

If this thesis is valid, the various easterly directions of pagan individual graves are not a matter of coincidence; rather they must be confined to the point at which the sun rises during the summer and winter solstice. On the day of the summer solstice the sun makes its largest arc and rises at the most north-eastern point. The true point at which the sun rises is dependent on the horizon. On the plain, where the horizon is open, the sun rises earlier, i.e. somewhat more northerly than can be detected from the angle of a cemetery that lies in front of an eastern mountain range. Here the sun first makes its elliptic path hidden behind the mountain crest so that on the same day of the year, the easterly direction of the point at which the sun rises has to differ from that on the plain. Studies of this phenomenon always prove that almost no grave was found to exceed the point at which the sun rises during the summer or winter solstice.

As for Christian doctrine, it is said that the body of Christ was laid with the head toward the west, that the risen Lord might face the eastern realm of eternal life and glory, and the Christian custom that sprang from this belief led to the usage of digging graves east and west, which prevailed through mediæval times, and is common with till to-day. In the twenty-fourth chapter of St. Matthew's gospel we read:

1 Bowen G.E. (2003), p. 173 referring to Eusebius Ecclesiastical History VII.13 2 Wells C., Green C. (1973), pp. 435-442. 
"For as the lightning cometh out of the east, and shineth even unto the west; so shall also the coming of the Son of man be"

Thence arose the belief that Jesus would, at the resurrection, appear from the east, and hence that those buried with their faces upward and their heads to the west, would be in readiness to stand up with their faces toward their Judge. ${ }^{1}$

\section{Conclusion: Threats and Recommendations}

The previous survey has shown that the necropolis of Karanis has an outstanding historical expansion and variation in beliefs and ideologies. Its graves are like a complete record of the tombs' state of their epochs. Therefore, they are considered of great value to the study.

An additional concern, on the basis of personal observations in 2008 , is that the site is under serious threat; the surface of the mounds has been subjected to wind erosion, causing many of the graves to be exposed and skeletal remains scattered around the area. One of the burials, obviously intact, provided a skeleton facing upward but not the slightest trace of anything else that could be used for dating or any other purpose (Fig.18). The grave was likely of a Coptic Christian. It is quite obvious that many individuals are either fully or partially skeletonised, due to the extremely arid environment of the Western Desert.

At any rate, this issue must catch the highest degree of attention for the necropolis is increasingly in danger of being lost forever or badly damaged. In addition to suffering the effects of erosion and the threats caused by weather, it is threatened by danger of destruction by large scale industrial and agricultural development.

The site is under serious risk, while recent work has shown that their potential to yield new information is enormous. A large scale survey and excavation project is needed in order to preserve and study such important remains. Also further studies needed for assessing surface skeletal material scattered throughout the cemetery's limits which would provide initial impressions on the lifestyle and health of the inhabitants of Karanis.

Truly, the investigation of the necropolis of Karanis leaves many questions unasked and others unanswered, further excavation should continue for more understanding concerning the Roman-Christian period of Egyptian history, especially in the Fayum.

1 Olcott W.T. (1914), pp. 267-268

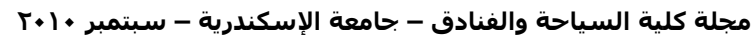




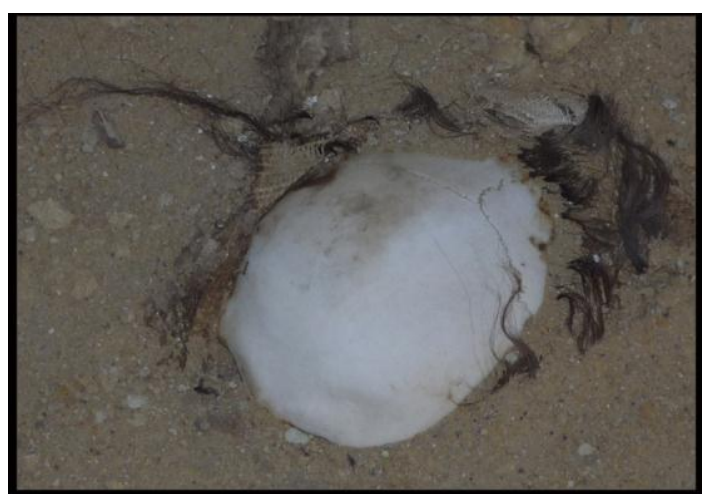

Fig.18 Exposed Grave Due to Wind Erosion (Author) Shows Skeletonised corpse, hair and wrappinas could be seen

Table of Some Coptic Names as occured on Grave Marker

\begin{tabular}{|c|c|c|c|}
\hline Grave Marker & $\begin{array}{c}\text { Coptic } \\
\text { Inscriptions }\end{array}$ & $\begin{array}{l}\text { Translation } \\
\text { Suggestion }\end{array}$ & References \\
\hline & $\begin{array}{l}d T \\
d \lambda l\end{array}$ & $\begin{array}{c}\text { dTdגid } \\
\text { Atalia was a } \\
\text { femal name }\end{array}$ & $\begin{array}{l}\text { Heuser 85; KRU } \\
475 A ; B M 554 B\end{array}$ \\
\hline & MOYPE & $\begin{array}{l}\text { MOYPEıßє } \\
\text { Most probably } \\
\text { Mourice }\end{array}$ & Heuser 119 \\
\hline & $\begin{array}{c}(--) d \\
(--) \text { MEl }\end{array}$ & $\begin{array}{c}\text { Пдмєі } \\
\text { was a common } \\
\text { Coptic names }\end{array}$ & Heuser 36 \\
\hline & $\begin{array}{c}(-) \text { NO (--) } \\
\text { 中IC }\end{array}$ & $\begin{array}{l}\text { dNOY } \phi I C \\
\text { Anofis seems to be } \\
\text { an Egyptian name }\end{array}$ & Pros.24 \\
\hline & $\begin{array}{l}\text { TEג } \\
\text { EN }\end{array}$ & $\begin{array}{c}\text { Unable to recon- } \\
\text { struct the name } \\
\text { the closest is } \\
\text { Teleme, Telemh, } \\
\text { Telemon }\end{array}$ & $\begin{array}{l}\text { Ryl. 250B; MIFAO 111 410; } \\
\text { Pros.42;M 85C, 84B; } \\
\text { CM 158A; COMH 47B }\end{array}$ \\
\hline & $\begin{array}{c}(--) \mathrm{T}(--) \\
\text { ClC }\end{array}$ & $\begin{array}{l}\text { Might be } \\
\text { dIIdCTdCIC } \\
\text { Meaning resurrection } \\
\text { or an Egyptian name } \\
\text { incorporating isis }\end{array}$ & $\begin{array}{c}\text { Aziz Atiya } 1972, \\
\text { p. } 357\end{array}$ \\
\hline 8 & $\begin{array}{c}(- \text { (-) dM(--) } \\
\text { aNI }\end{array}$ & $\begin{array}{l}\text { Mostly } \\
\text { dMIMCNI } \\
\text { An Egyptian Name } \\
\text { driven from Amon }\end{array}$ & $\begin{array}{l}\text { Pros. 20; Heuser 45; } \\
\text { Kellia II 165; } \\
\text { SaW 244; CPR IV } \\
203 \text { A }\end{array}$ \\
\hline
\end{tabular}

(32)

مجلة كلية السياحة والفنادق - جامعة الإسكندرية - سبتمبر • | • 


\section{About the Table of Some Coptic Names ${ }^{1}$}

The abbreviations used in the table are following the classification of Hasitzka in her thorough monograph on the names known from Coptic documentary texts as follows:

$\mathbf{B M}=$ W. E. Crum, Catalogue of the Coptic Manuscripts in the British Museum, London 1905

CPR IV= W. C. Till, Die koptischen Rechtsurkunden der Papyrussammlung der Österreichischen Nationalbibliothek, Wien 1958 (Corpus Papyrorum Raineri, Bd. 4)

Heuser = G. Heuser, Die Personennamen der Kopten, Leipzig 1929 (Stud. zur Epigraphik und Papyruskunde, Bd. 1, Schrift 2)

Kellia II $=$ R. Kasser, Kellia. Topographie (Recherches Suisses d'archéologie copte, $\mathrm{Bd}$. 2)

KRU = W. E. Crum, G. Steindorff, Koptische Rechtsurkunden des 8 . Jh. aus Djeme (Theben), Leipzig 1912

Pros. = G. Heuser, Prosopographie v. Ägypten IV. Die Kopten, Heidelberg 1938 (Quellen und Studien zur Geschichte und Kultur des Altertums und des Mittelalters, Reihe C: Bd. 2)

SaW = C. Wietheger, Das Jeremias-Kloster zu Saqqara unter besonderer Berücksichtigung der Inschriften, Altenberge 1992 (Arbeiten zum spätantiken und koptischen Ägypten, Bd. 1)

Aziz A. = Hanna, Sami A. Medieval and Middle Eastern Studies in Honor of Aziz Suryal Atiya . Leiden: Brill, 1972.

$\mathbf{C M}=\mathrm{W}$. E. Crum, Coptic Monuments (Catalogue génerál des Antiquités Égyptiennes du Musée du Caire, Bd. 4)

COMH = E. Stefanski, M. Lichtheim, Coptic Ostraca from Medinet Habu, The University of Chicago. Oriental Institute Publications, Bd. 71. Chicago 1952

Ryl. = W. E. Crum, Catalogue of the Coptic Manuscripts in the Collection of the John Rylands Library Manchester, Manchester 1909

1 For assistance in copying letters and translating the author is indebted to Mr. Nader Alfy, (Assistant lecturer at Menofia University).

2 For further study and compete bibliography of Coptic Names see: Hasitzka M. (2004), "Namen in Koptischen dokumentarischen Texte" electronic document available at: http://www.onb.ac.at/sammlungen/papyrus/publ/kopt_namen.pdf.

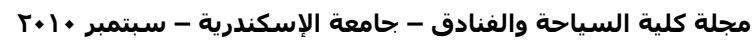




\section{Appendix \\ Karanis Necropolis: Note on the Pottery Vessels}

During the excavation which carried out by the Fayum Inspectorate of Antiquities at the cemetery of Karanis, many complete pottery vessels have been discovered shows variety of types and functions. All these vessels come either from the topsoil layer or from upper fill deposits. Common-wares apparently prevail in the collection. All the type-forms are a representative cross-section of the $5^{\text {th }}-7^{\text {th }}$ century repertoire and can be readily paralleled in material found on other Egyptian sites dated to the late Roman period particularly to the time between $5^{\text {th }}$ and $7^{\text {th }}$ century $\mathrm{AD} .{ }^{1}$

Their Description: (Fig: 19, 20 PL. I - III)

R882, ring based bowl with out ledge rim, eastern terasigilata ware, fine, dense earthen ware in pink fracture - the surface is plain in light red color of 10R6/6, the outer surface is incised with vertical lines.

$\mathbf{R 8 8 3}$, round bottomed lid with inner loop handle, made of coarse Nile silt in refracture, tempered with lots of chaff and dung - the surface is plain in red color of $10 \mathrm{R} 4 / 8$, the inner surface is decorated with white colored circles.

R890, an example of 5 round bottomed, cylindrical Amphorae, made of Egyptian marl ware in pale yellow fracture tempered with sand, limestone and dark rocks particles - the surface is plain in very pale brown color of 10YR7/3, This Amphora has such a distinctive shape and fabric accordingly it was probably made in a single pottery work shop which might be near Abu Mina monastery in the western Delta. ${ }^{2}$ The Amphora found in all the Nile valley from Alexandria to Sudan, in Rome, Spain, north Africa, Cyprus, Palestine and Turkey, this Amphora vary in date between $4^{\text {th }}$ and $7^{\text {th }}$ century AD. ${ }^{3}$ Amphora often inscribed on the shoulder by red or black inscription which appropriately named "acrobatic script", this inscriptions are extremely difficult to read but seem to consist of the potter's name, content and the capacity of the vessel.

R891/1, round bottomed cooking pot without handles made of Nile silt in red fracture tempered with lots of fine chaff and few of sand and limestone particles - the surface is plain in weak red color of 10R5/4, the outer surface is smeared with black interpreters that the pot were in use.

1 Majcherek G. (1992), pp. 81-117; Egloff M. (1977); Godlewski W., et al. (1994), 216-235.

2 Empereur J.Y., Picon M. (1998), pp. 75-91; Engemann J. (1992), pp. 153-159

3 Egloff M. (1977), pp. 113-115, pl. 22:3-5, 11; 57:7; 61:4-6. Amphorae of this class in Alexandria are normally associated with the 7th-8th century deposits, $c f$. G. Majcherek, pp. 81-117. Several examples have been reported also from Fayum, cf. W. Godlewski et al., $p$. 232, pl. 21:2-3.

مجلة كلية السياحة والفنادق - جامعة الإسكندرية - سبتمبر • + T 
R891/2, round bottomed, ribbed cooking pot with 2 handles made of fine Nile silt in red fracture with black core tempered with fine sand and few of fine chaff - the surface is plain in red color of $2.5 \mathrm{YR} 5 / 6$, the outer surface is smeared with black interpreters that the pot were in use.

R893, Egyptian brown ribbed Amphora made of fine alluvial Nile silt in red fracture boarded with brown, surface is plain in reddish brown color of 2.5YR5/4. The Egyptian brown Amphora widely distributed through Egypt, very standard Amphora for the Delta wine, occurred frequently in the Mediterranean countries during the Ptolemaic and Roman period. ${ }^{1}$

R894, ring based jar with out ledge rim, made of fine alluvial Nile silt in brown fracture with lots of mica - the outer surface is slipped by red color of $10 \mathrm{R} 5 / 5$ while the inner surface is plain in light reddish brown color of 5 YR6/4.

R895, ring based, open mouth jar, made of coarse Nile silt in red fracture tempered with lots of chaff and sand - the surface is plain in weak red color of 10R5/4.

R896, flat bottomed, small size pitcher made of Gray Egyptian marl ware (Qena ware) tempered with sand and red, gray and brown dark rocks, all might be occurred naturally in the row material - the surface is plain in light gray color of $5 Y 7 / 2$.

R897, flat bottomed, small size jar, made sandy, Egyptian marl ware in red fracture; the outer surface is slipped by light gray color of $5 Y 7 / 2$ while the inner surface is plain in light red color of 10R6/6.

R900, round bottomed, small size bowl, made of fine, sandy Nile silt in brown fracture tempered with lots of dark rock particles and mica both surfaces are slipped and burnished by red color of 10R5/6.

R909, ring based, medium size pitcher made of Gray Egyptian marl ware (Qena ware) tempered with sand and red, gray and brown dark rocks, all might be occurred naturally in the row material - the surface is plain in light gray color of $5 \mathrm{Y} 7 / 2$.

Although most of the relevant pottery provides only summary datings, it is clear that the excavated material as a whole should be attributed to a chronological horizon ranging from the late $5^{\text {th }}$ to the end of the $7^{\text {th }}$ century $\mathrm{AD}$, with some forms continuing well into the 8 th century.

\section{Hints on Some Artifacts Uncovered}

Oil Lamps: (PL. IVa,b,c,d)

R885, R887, R899: (Pottery) The excavations have yielded some pottery oil lamps (a few from the same mould!). These are highly

1 It belongs to the late shoulder-edged version dated to the late 6th-early 7th century AD, $c f$. Majcherek G. (1995), pp. 163-178; Id. (1992), p.7; Egloff M. (1977), pp. 173-178

مجلة كلية السياحة والفنادق - جامعة الإسكندرية - سبتمبر • +1 T 
typical Byzantine lamps with rays or relief circles, or grapevine clusters on the shoulders, dated commonly to the years AD 550-650. ${ }^{1}$

R887: Appears to be early Islamic in design and execution. The decorative motifs that are found at its bottom show a crescent and small rectangle with illegible inscription.

R884: (Bronze) Two elongated bronze oil lamps from the Roman or early Christian period, with central filling hole. The first has two elongated nozzles, with hanging the suspension is in the form of a chain. The other has only one spout and a handle

\section{Terracotta Figurines: (PL. IV e,f)}

R906: The discovery of terracotta figurines of a robed figure depicting a maternal, possibly the Virgin Mary-like figure, suggests the arrival and widespread adoption of Christianity.

R888: A terracotta figurines of a horse $(H .12 .8 \mathrm{~cm}, \mathrm{~L} .10 \mathrm{~cm}$.). The decorative motifs imitate the horsehair, packsaddle and bridle. It recalls those statuettes found in the settlement

\section{Jewelery: (PL. V a-f)}

The resemblance with the products found in many other sites in Egypt would suggest that the Jewelry items were locally made and that they must have been manufactured in the Late Romano-Coptic period workshops and therefore ascribed to $5^{\text {th }}-6^{\text {th }}$ century AD. However, the collection contains relatively few examples of absolute Coptic jewelry, quite understandably, for little has survived. Two necklaces of ivory beads were found in 2003 with a cross-shaped pendant. ${ }^{2}$

Jewelry items unearthed include: Bead necklaces R904, R913: strand of multi-colored random beads of stone, glass, ivory and faience; Bracelets R905: Copper alloy bracelets, R908: 2 Bronze bracelets; R907: 7 Bronze rings; Copper alloy anklets and cord earrings. ${ }^{3}$

R889: Two pendants made of a blue glass paste and pierced to be suspended from the necklace; the $\mathbf{1}^{\text {st }}$ is bigger, almost circular, with a crescent in its center. Decorations around the crescent represent circles probably represent the Stars. The small pendant is in the form of a crescent.

Even so, mortuary goods recovered during the excavation indicate that grave goods were few and rather modest. Individuals were buried with plain or painted ceramic pots or bowls and some of their jewelry.

1 Bailey D.M. (1988), p. 269, Q 2228, pl. 53, 144, fig. 141; 274, Q 2266, pl. 55; cf. Shier A. (1978), pp. 45-47, pl. 7:422.

2 'Record of Objects Books' of Kom Aushim museum nr. R987, R988

3 For ankles cf. 'Record of Objects Books' of Kom Aushim museum nr. R992. Also a gold ear ring was discovered $n r$. R881(now in Egyptian Museum) 
Fig.19 Pottery Vessels

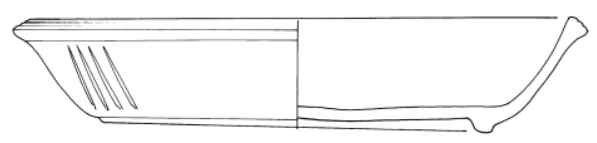

R882 scale 1:4
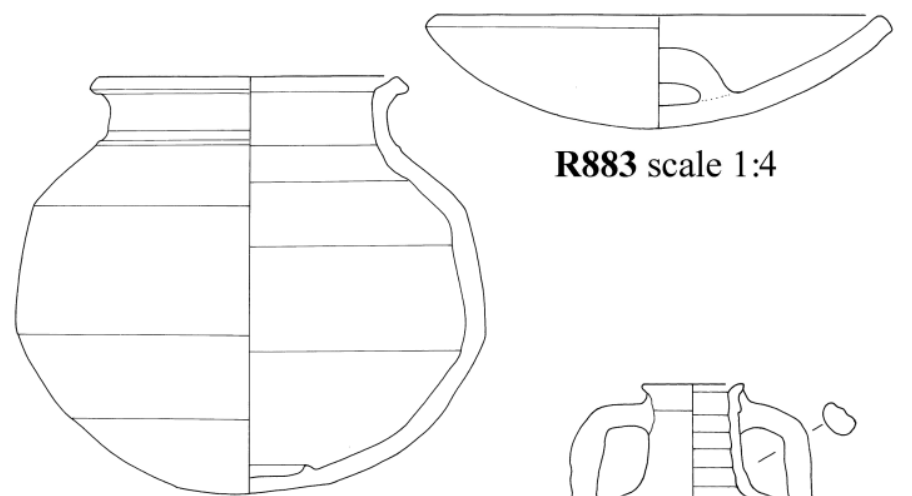

R891/1 scale 1:4

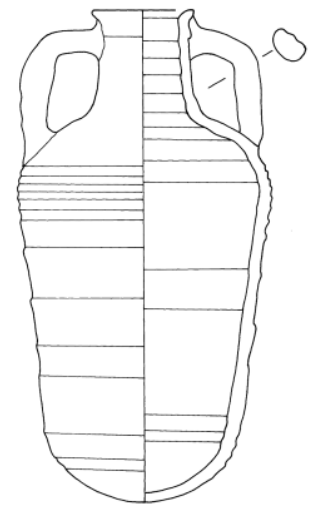

R890 scale 1:8

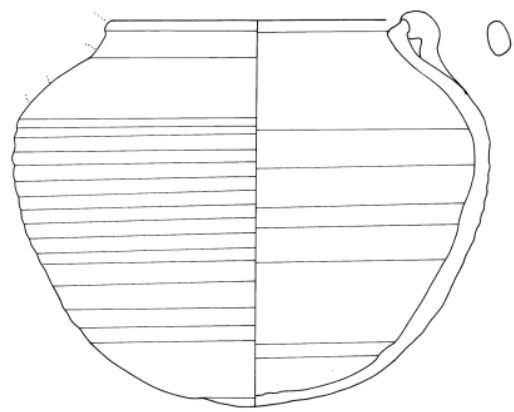

R891/2 scale 1:4 
Fig.20 Pottery Vessels

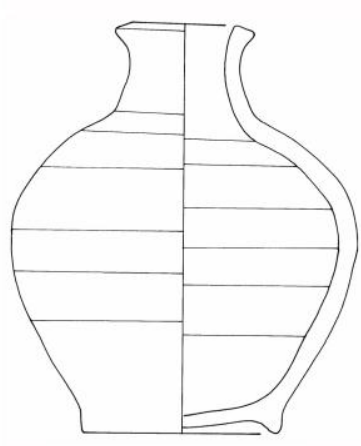

R894 scale 1:4

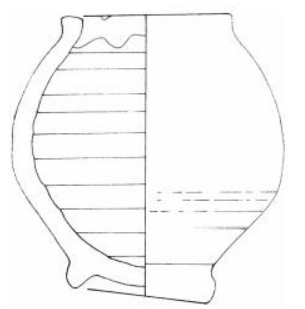

R895 scale 1:4

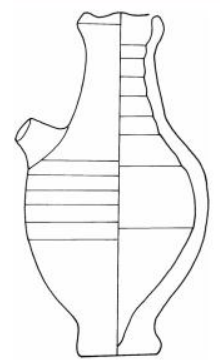

R896 scale 1:4

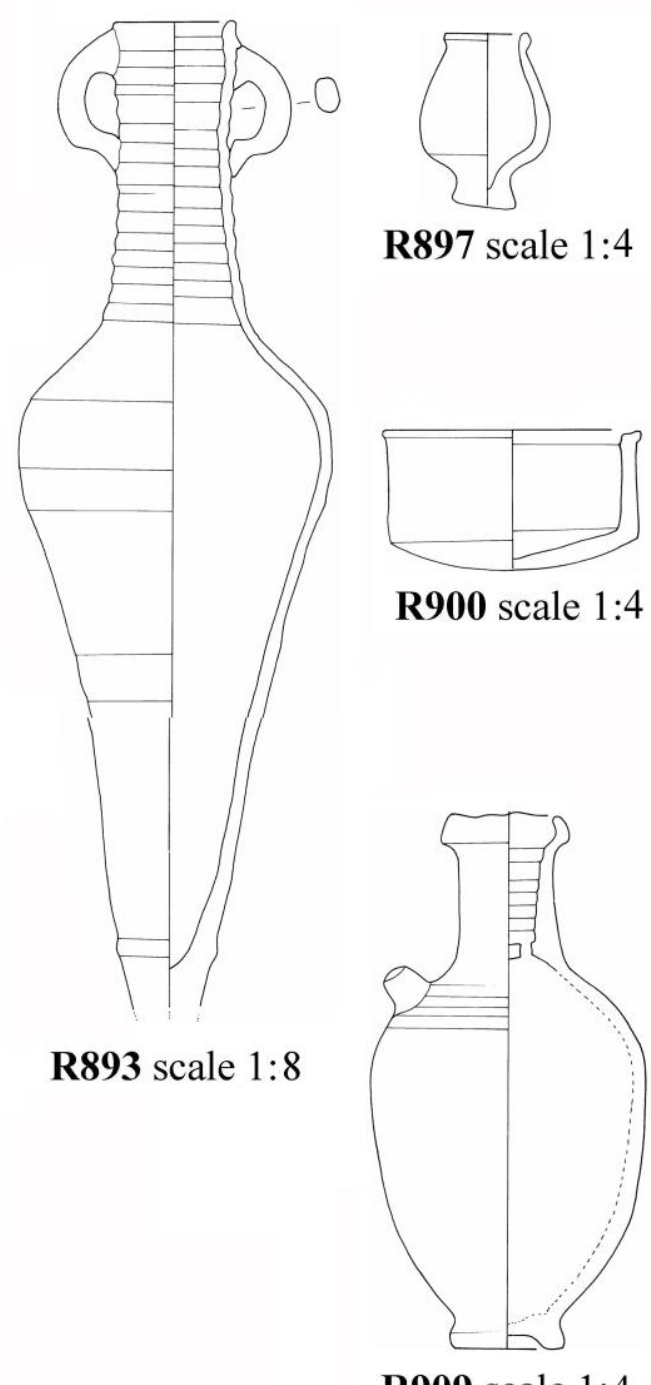

R909 scale 1:4 
PL. I

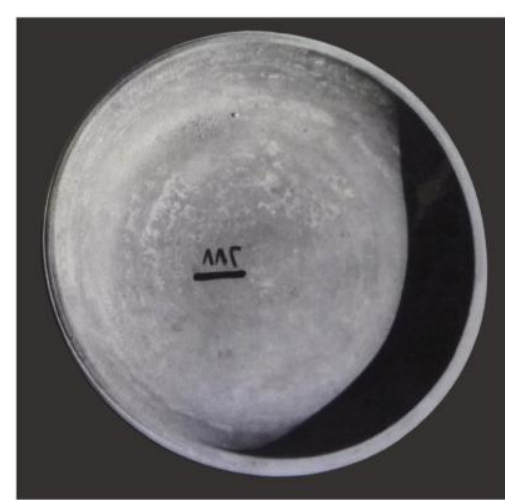

(a) $\mathrm{R} 882$

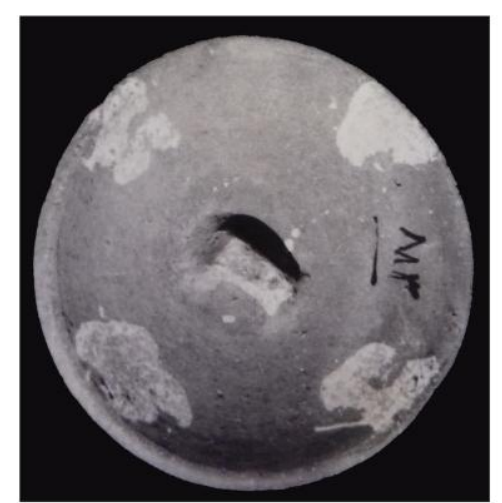

(b) R883

(c) R890

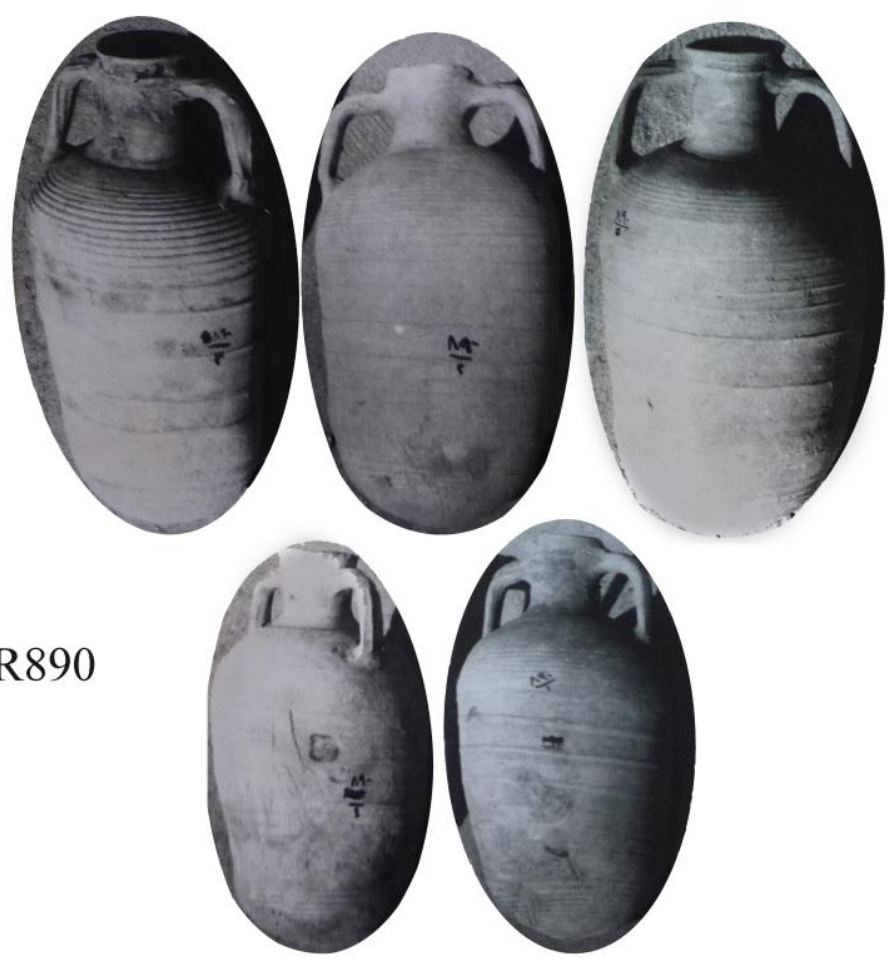

مجلة كلية السياحة والفنادق - جامعة الإسكندرية - سبتمبر • ا• ؟ 
PL. II

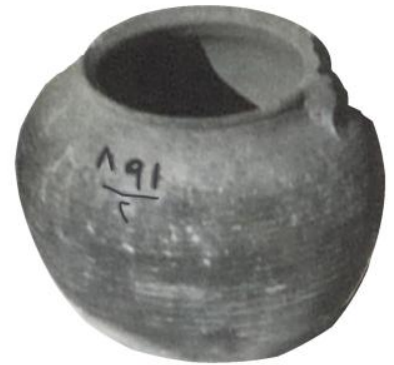

(a) $\mathrm{R} 891 / 1,2$

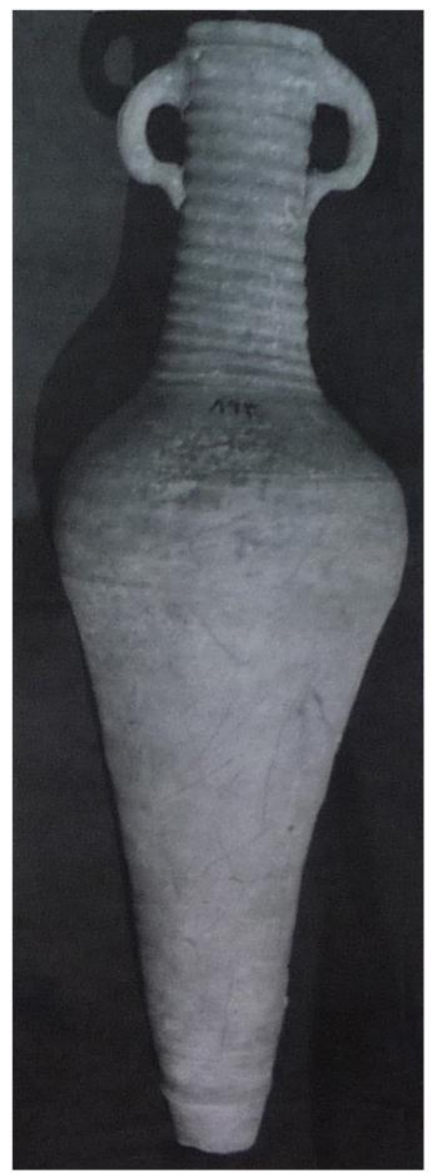

(b) R893

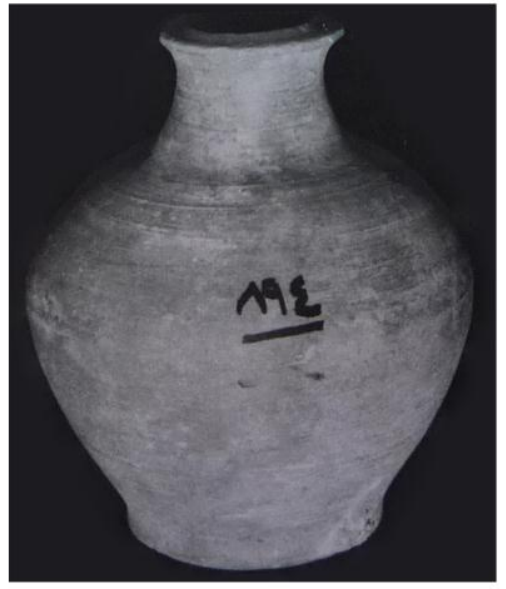

(c) R894

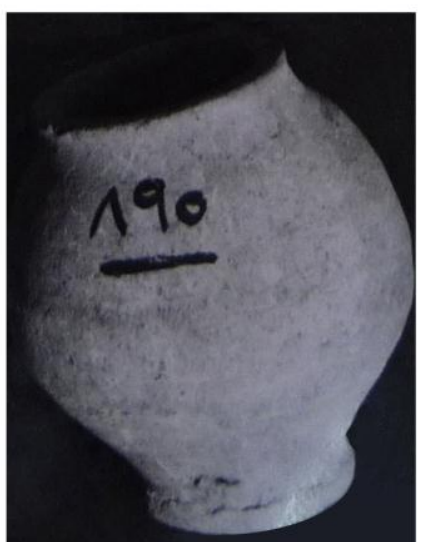

(d) R895 
PL. III
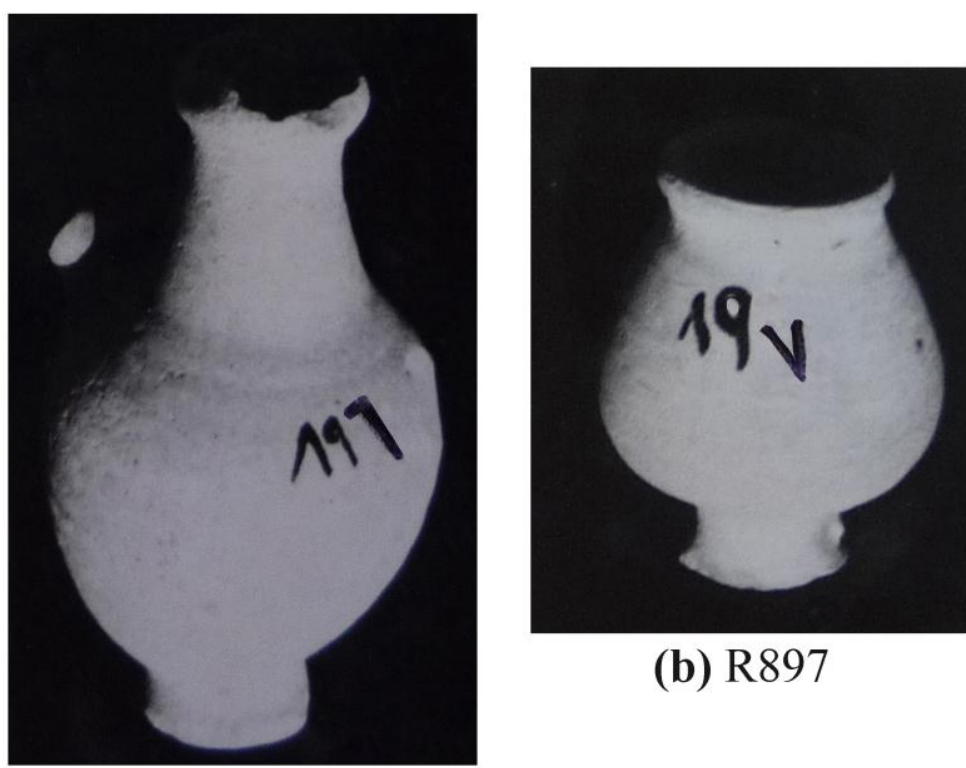

(b) R897

(a) R896
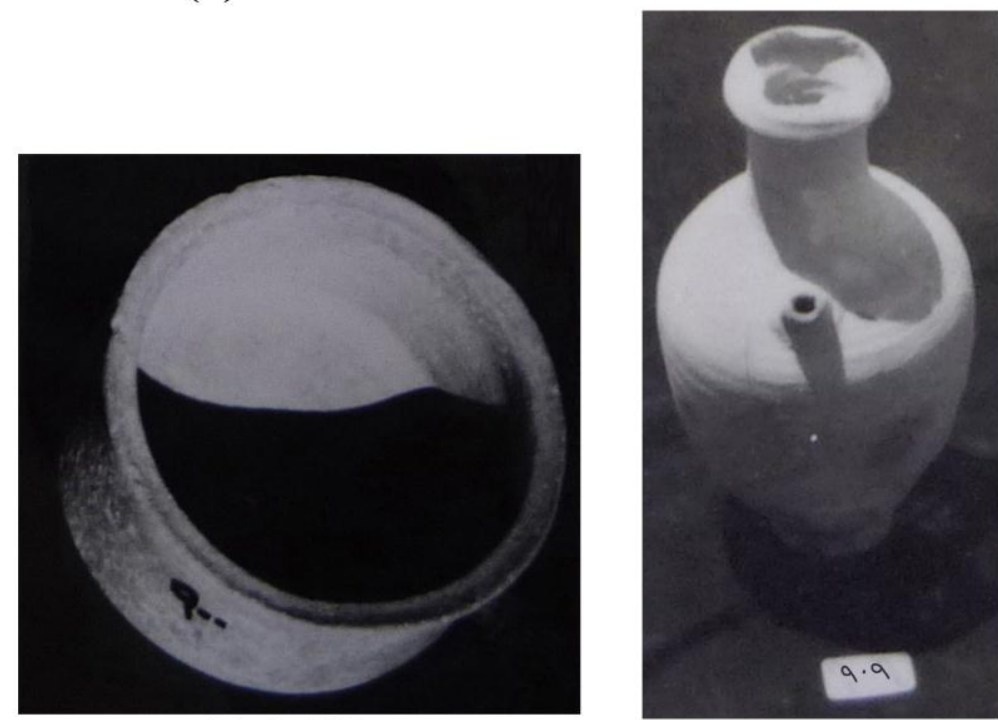

(c) $\mathrm{R} 898$

(d) R909 


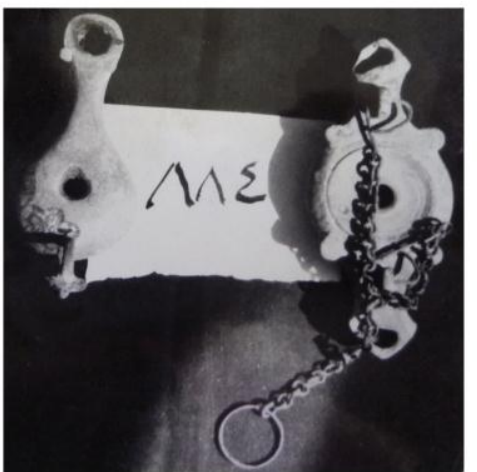

(a) R884

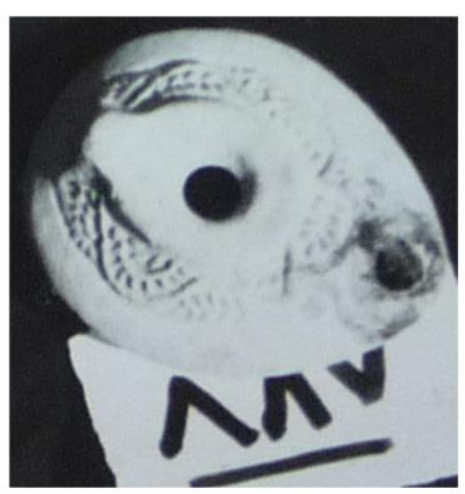

(c) $\mathrm{R} 887$

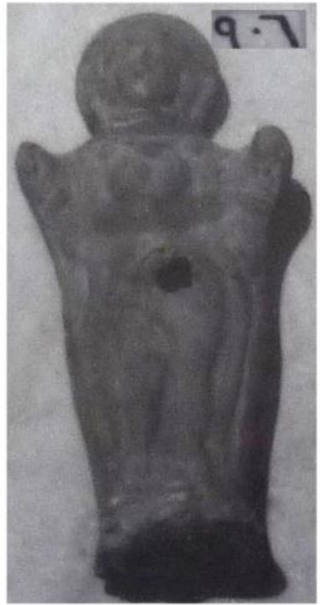

(e) R906
PL. IV

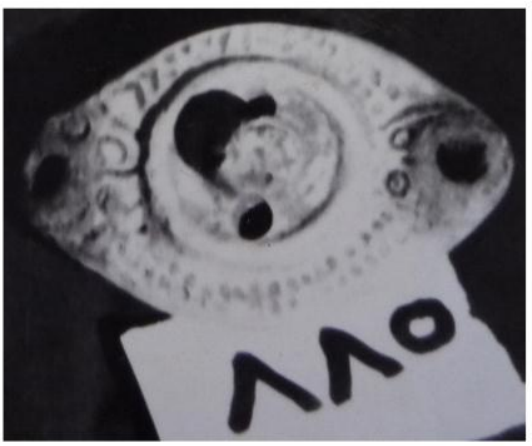

(b) R885

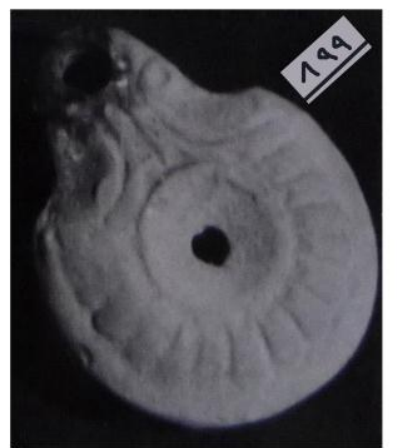

(d) R899

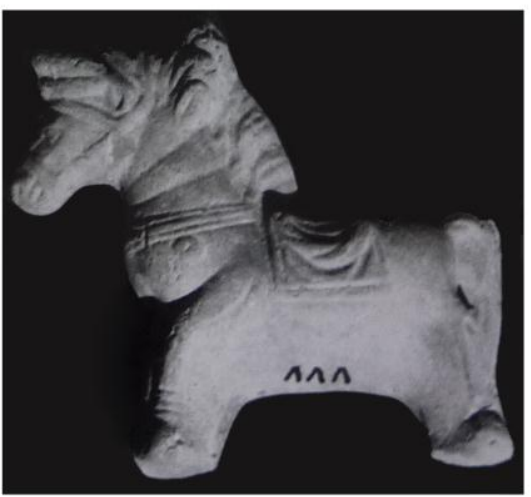

(f) $\mathrm{R} 888$ 

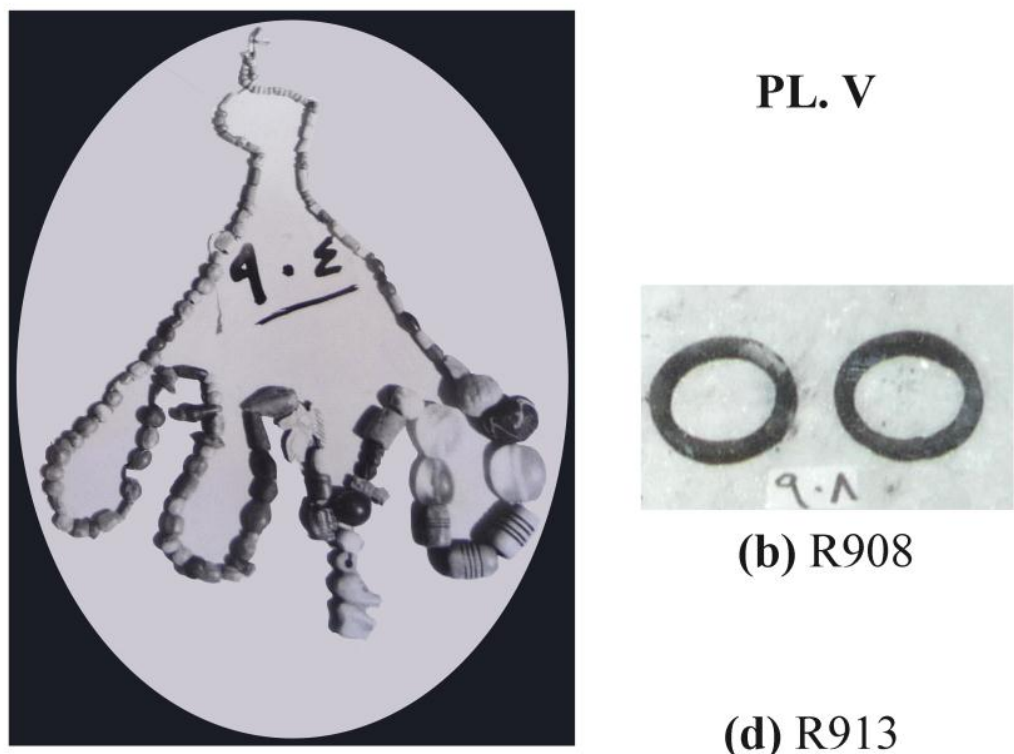

(b) R908

(a) R904

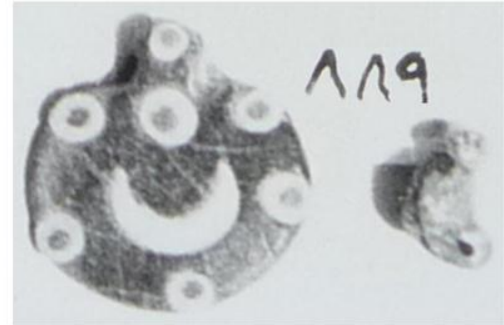

(c) R889
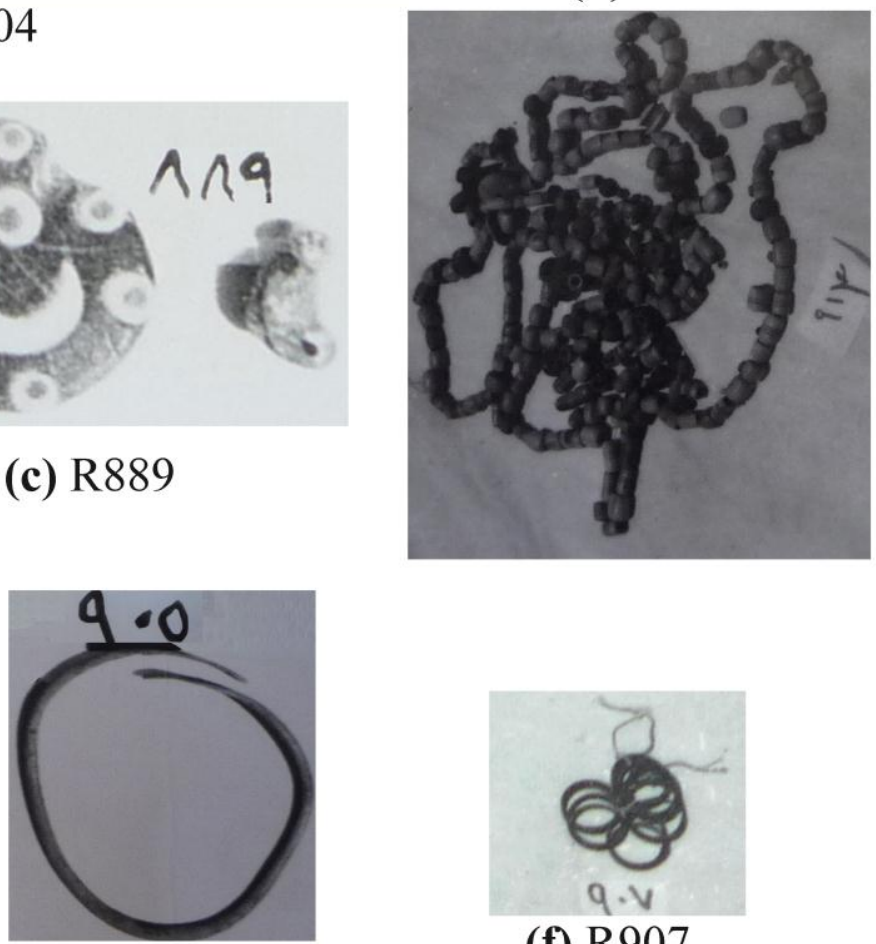

(e) R905

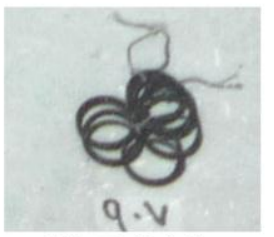

(f) R907

r • • 


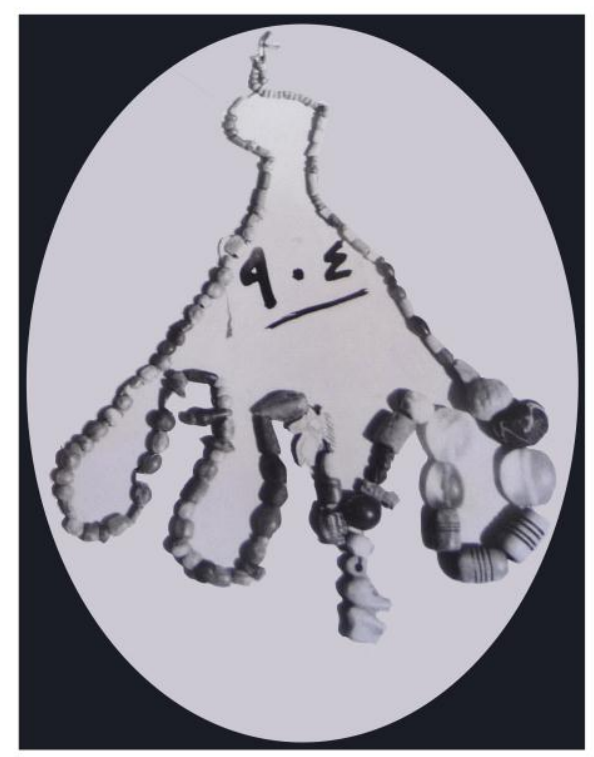

PL. V

(a) R904

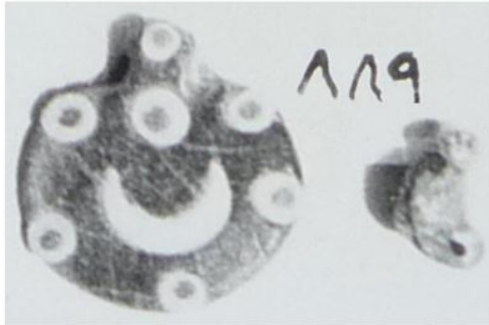

(c) R889

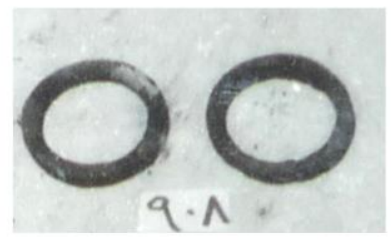

(b) R908

(d) R913
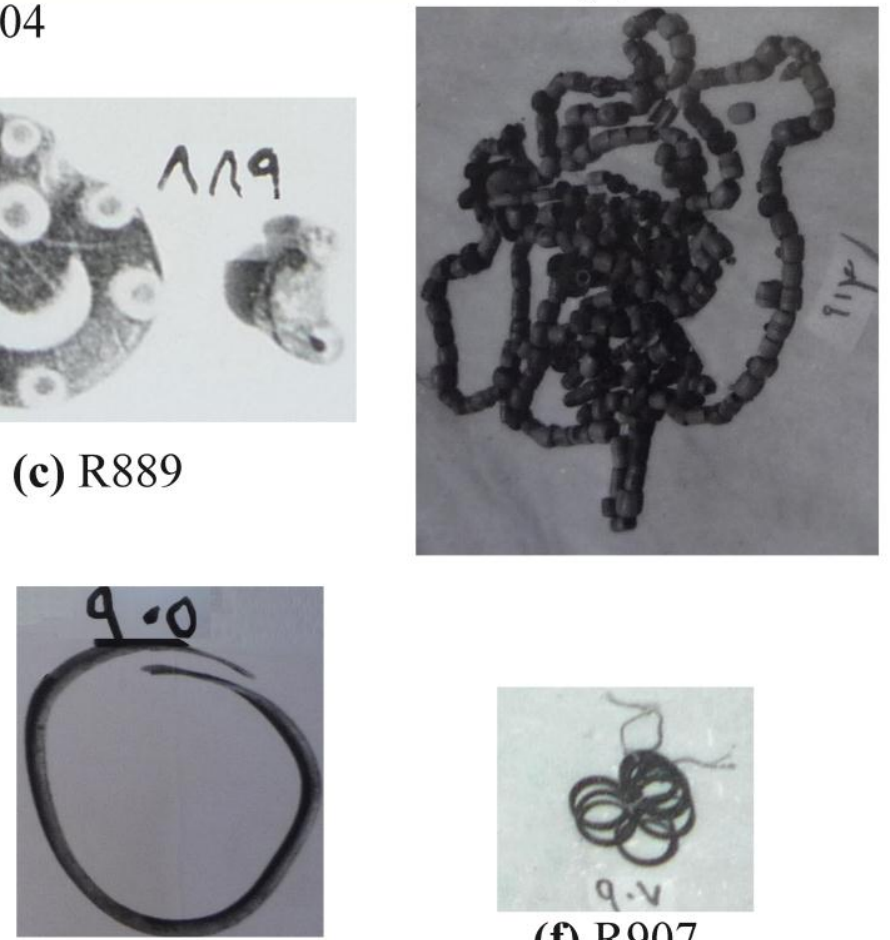

(e) R905

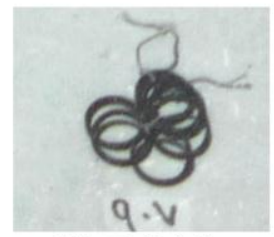

(f) R907 


\section{Bibliography:}

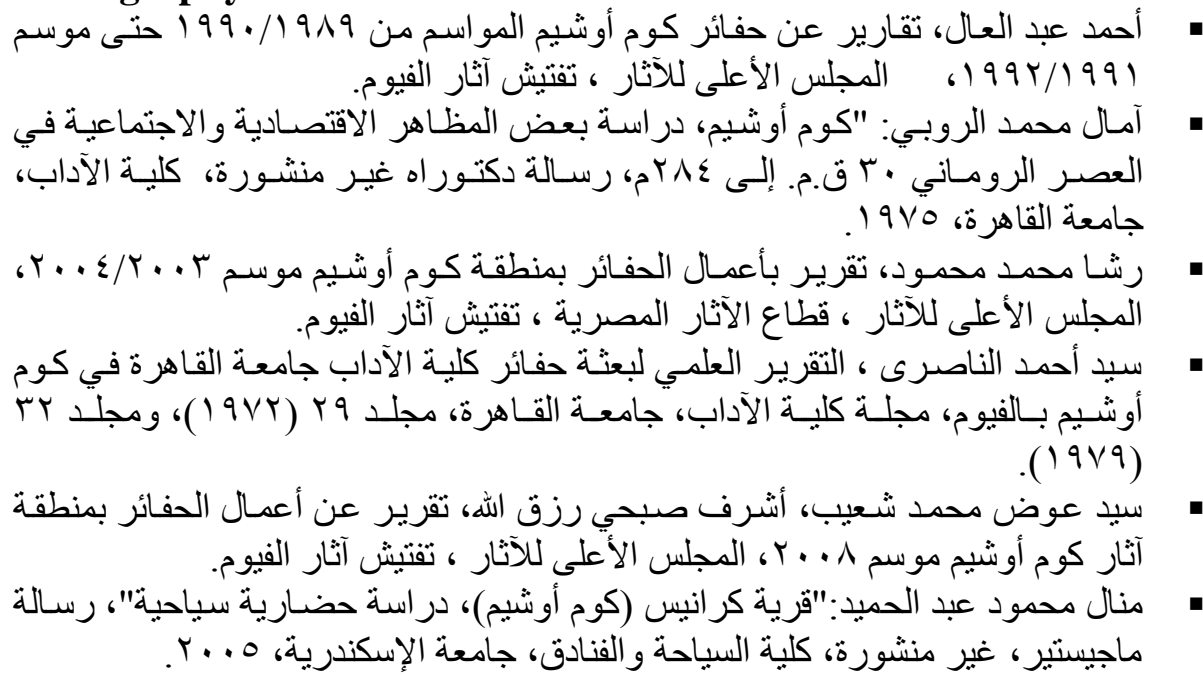

- Albright W. F. (1932), "An Anthropoid Clay Coffin from Sahab in Transjordan", AJA 36.3, 295-306.

- Allen M.L. (1985), The Terracotta Figurines from Karanis: A Study of Technique, Style, and Chronology of Fayoumic Coroplastics 1-2, Ann Arbor.

- Alston R.A. (1995), Soldier and Society in Roman Egypt: A Social History, London and New York.

- Badawy A. (1953) “'La Stèle Funéraire Egyptienne à Ouverture Axial”, BIFAO 35, 117-139

- Ball J. (1952), Contributions to the Geography of Egypt, reprinted by Survey of Egypt, Cairo

- Bagnall R.S. (1993), Egypt in Late Antiquity, Princeton University Press: Princeton.

- -------------. (2001), "Archaeological Work on Hellenistic and Roman Egypt, 1995-2000”. AJA 105, 227- 43.

- Bailey D.M. (1988), Catalogue of the Lamps in the British Museum, III. Roman Provincial Lamps, London.

- Bard K.A., Shubert S.B. (1999), Encyclopedia of the Archaeology of Ancient Egypt, Routledge, London.

- Bell H. I. (1952), "Family Life at Karanis", The Classical Review, NS, Vol.2, No.3/4 (Dec.), 185-186.

- Blackman A.M. (1912), "The Significance of Incense and Libations in Funerary and Temple Ritual," ZAS 50, 69-75.

- Bloxam E.G., Storemyr P. (2002), "Old Kingdom Basalt Quarrying Activities at Widan el-Faras, Northern Faiyum Desert". JEA, 88, 23-36. 
- Boak A.E. (1926), "Irrigation and Population in the Fayum, the Garden of Egypt", Geographical Review, 16.3.

- --------- (1926), "The University of Michigan's Excavations at Karanis: 1924-5", JEA 12, No. 1/2 (April), 19-21.

- --------- (1955), "The Population of Roman and Byzantine Karanis," Historia: Zeitschrift für Alte Geschichte, Vol. 4, No. 2/3, 157-162.

- Boak, A.E., Peterson E.E. (1931), "Karanis: Topographical and Architectural Report of Excavations During the Seasons 1924-28", University of Michigan Humanistic Series, vol. 25, Ann Arbor

- Boak A.E., Youtie H.C. (1960), The Archive of Aurelius Isidorus in the Egyptian Museum, Cairo, and the University of Michigan, Ann Arbor.

- Bourguet P. Du. (1964), L'art Copte, Petit Palais, Paris.

- Bowen G.E. (2003), "Some Observations on Christian Burial Practices at Kellis". The Oasis Papers 3: Proceedings of the First International Conference of the Dakhleh Oasis Project, Bowen GE, Hope CA (eds.), Oxford, 167-182.

- Bowman A.K., (1986), Egypt after the Pharaohs: 332 BC-AD 642 from Alexander to the Arab Conquest, California.

- Budge E.A.W. (1987), The Mummy: A Handbook of Egyptian Funerary Archaeology, London

- Butler A.J. (2004), The Ancient Coptic Churches of Egypt, Piscataway, N.J., Gorgias Press.

- Butzer K.W., (1976), Early Hydraulic Civilization in Egypt: A Study in Cultural Ecology, Chicago.

- Crawford D., (1971), Kerkeosisris, an Egyptian Village in the Ptolemaic Period, Cambridge, Cambridge University Press.

- Curl J.S. (1994), Egyptomania. The Egyptian Revival: A Recurrent Theme in the History of Taste, Manchester.

- Daressy G. (19I7), Le Couvent de Nahieh, Cairo.

- Davies J. (1999), Death, Burial and Rebirth in the Religions of Antiquity, Routledge, London and New York.

- Davoli P. (1998), L'archeologia Urbana nel Fayyum di Età Ellenistica e Romana. Missione Congiunta delle Università di Bologna e di Lecce in Egitto, Napoli

- Diodorus Siculus (1946), Library of History. Trans. By Oldfather C. H., Loeb Classical Library, London, Book I

- Egloff M. (1977), Kellia: La poterie Copte: 4 Siècles d'Artisanat et d'Échanges en Basse-Égypte, Genève. 
- Egyptian General Survey Authority (E.G.S.A.) (1995), Maps of scale 1:50000, through the Transverse Mercator Projection, derived from aerial photographs.

- El-Fakharani F.A. (1983), "Recent Excavation at Marea in Egypt", Sonderdruck das Römisch-Byzantinische Ägypten, Ägyptiaca Treverensia, Trierer Studien zum Griechisch-Römischen Ägypten, 175-186.

- Empereur J.Y., Picon M. (1998), " Les Ateliers d'Amphores du Lac Mariut", BCH Suppl. 33, 75-91.

- Emery W.B. (1961), Archaic Egypt, Harmondsworth.

- Erman A. (1966), Ancient Egyptians, New York.

- Francia L. Del. (1991), "Symbols in Coptic Art: Alpha and Omega", The Coptic Encyclopedia, VII.

- Frankfurter D. (1998), Religion in Roman Egypt: Assimilation and Resistance, Princeton University Press: Princeton.

- Garbrecht G., (1987), "Water Storage (Lake Moeris) in the Fayum Depression, Legend or Reality?", Irrigation and Drainage Systems, no.1, p.143-157.

- Gardiner A.H., Bell H.I.(1943), "The Name of Lake Moeris," JEA 29, 37-50.

- Gazda, E.K. (1978), Guardians of the Nile: Sculptures from Karanis in the Fayoum (c.250 BC-AD 450), Ann Arbor.

- ---------- (1983), Karanis, An Egyptian Town in Roman Times: Discoveries of The University of Michigan Expedition to Egypt 1924-1935. Ann Arbor: Kelsey Museum of Archaeology.

- Gazda E.K., Wilfong T. (2005), Karanis: An Egyptian Town in Roman Times, Ann Arbor.

- Geremek H., (1969), Karanis, communauté rurale de l'Égypte romaine au $\mathrm{II}^{\mathrm{e}}-\mathrm{III}^{\mathrm{e}}$ siècle de notre ère, Archiwum Filologiczne, no. 17 .

- Godlewski W., Derda T., Górecki T. (1994), "Deir el Naqlun (Nekloni).Second Preliminary Report", Nubica III.1,216-235

- Grenfell, B. P., Hunt, A. S., Hogarth, D. G., \& Milne, J. G. (1900). Fayum Towns and their Papyri. London: Egypt Exploration Fund.

- Gero S. (January - April 1977), "The So-Called Ointment Prayer in the Coptic Version of the Didache: A Re-evaluation", Harvard Theological Review 70, 74-80.

- Griggs C.W. (1988), "Excavating a Christian Cemetery Near Selia, in the Fayum Region of Egypt," in Excavations at Seila, Egypt, ed. C. Wilfred Griggs, Provo, Utah: Religious Studies Center, Brigham Young University, 74-84.

- Habib R. (1967), The Coptic Museum, Cairo.

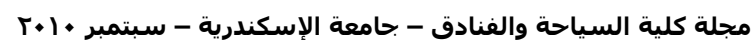


- Harden, D.L. (1936), Roman Glass from Karanis Found by the University of Michigan Archaeological Expedition in Egypt 192429, Ann Arbor

- Harrell J. A., Bown T. M. (1995), An Old Kingdom Basalt Quarry at Widan el-Faras and the Quarry Road to Lake Moeris in the Faiyum. JARCE, 32: 71-91.

- Hassan, F.A. (1986), "Holocene Lakes and Prehistoric Settlements of the Western Faiyum, Egypt", Journal of Archaeological Science, Vol.13, 483-501.

- Haatvedt R.A. and E.E. Peterson (1964), Coins from Karanis: the University of Michigan Excavations, 1924-1935, ed. E.M. Husselman, Ann Arbor.

- Hauser W. (1932), "The Christian Necropolis in Khargeh Oasis", BMMA 27, 38-50.

- Herodotus, Histories. Trans. by Cary H. (1912), Bohn's Classical Library, London, Book II

- Hussain A.G. (1983), "Magnetic Prospecting for Archaeology in Kom Oshim and Kiman Faris, Fayoum, Egypt", ZÄS 110, 36-51

- Husselman E.M. (1979), Karanis Excavations of the University of Michigan in Egypt 1928-1935: A Summary of the Reports of the Director, Enoch E. Peterson, Ann Arbor.

- Jeffreys, D.G., Strouhal E. (1980), "North Saqqara 1978-9: The Coptic Cemetery Site at the Sacred Animal Necropolis Preliminary Report", JEA 66, 28-35.

- Johnson B. (1981), Pottery from Karanis: Excavations of the University of Michigan, Ann Arbor

- Johnson M. J. (1999), Pagan-Christian Burial Practices of the Fourth Century: Shared Tombs? Christianity and Society The Social World of Early Christianity, Garland Publishing, Inc. New York and London, 37-59.

- Judge E.A. (1977), "The Earliest Use of Monachos for Monk (P.Coll.Youtie77) and the Origins of Monasticism", JAC 20, 7289.

- Kamel I. (1987), Coptic Funerary stelae, Catalogue Général Des Antiquités Du Musée Copte, Le Caire.

- Kamil J. (2002), Christianity in the Land of the Pharaohs: The Coptic Orthodox Church, London: Routledge.

- - ---- (1983), Coptic Egypt , Cairo.

- Keenan J. G. (2003), "Deserted Villages: From the Ancient to the Medieval Fayyúm", BASP 40, 119-140

- Keenan J. G., (2005) "Landscape and Memory: al-Nabulsi's Ta'rikh al-Fayyum," BASP 42, 203-212. 
- Kitchen K. A. (Dec., 1961), "An Unusual Stela from Abydos", JEA 47, 10-18

- Kozolowski J. K., Ginter B. (1993), Holocene Changes in the Fayum: Lake Moeris and the Evolution of Climate in Northeastern Africa. In Environmental Change and Human Culture in the Nile Basin and Northern Africa Until the Second Millennium BC (eds L. Krzyzaniak, M. Kobusiewicz and J. Alexander). Poznan: Poznan Archaeological Museum, 327-36.

- Kurtz, Donna C., and Boardman J. (1971), "Greek Burial Customs", New York.

- Lesko L.H. (1988), "Seila 1981", JARCE 25, 215-235.

- Littman R. J., Littman M. L. (1973), "Galen and the Antonine Plague", The American Journal of Philology, Vol. 94, No. 3 (Autumn), 243-255.

- Majcherek G. (1995), "Gazan Amphorae: Typology Reconsidered", in: Hellenistic and Roman Pottery in the Eastern Mediterranean (Advances in Scientific Studies), The Second Nieborrow Workshop, Warsaw, 163-178.

- ---------- (1992), "Late Roman Ceramics from Sector G", Études et Travaux 16, 81-117.

- Morenz S. (1994), Egyptian Religion, New York

- Noshy I. (1937), "The Arts in Ptolemaic Egypt- A Study of Greek and Egyptian influences in Ptolemaic architecture and sculpture", London.

- Olcott W.T. (1914), "Solar Significance of Burial Customs", Chapter XI in Sun Lore of All Ages: A Collection of Myths and Legends Concerning the Sun and Its Worship, New York and London.

- Pelsmaekers J. (1991), "Stela", The Coptic Encyclopedia, VII, New York.

- Perry W.J. (1925), "The Cult of the Sun and the Cult of the Dead in Egypt", JEA 11, London, 191-200.

- Petrie W.F. (1892) Ten Years of Digging in Egypt: 1881-1891, London: The Religious Tract Society

- Pollard N. (1998), "The Chronology and Economic Condition of Late Roman Karanis: An Archaeological Reassessment". JARCE 35, 147-162.

- Rea J. (1993), "P. Haun. III 58: Caranis in the Fifth Century," ZPE 99, 89-95.

- Rice M. (1997), Egypt's Legacy, London.

- Rowland J. (2008), "The Ptolemaic-Roman Cemetery at the Quesna Archaeological Area", JEA 94, 69-93.

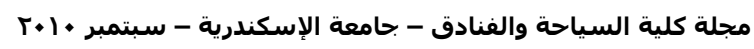


- Sabbahy L. (2009), "Catalogue General of Egyptian Antiquities in the Cairo Museum: Nos. 17037-17091, 7127-7219; Anthropoid Clay Coffins", SCA press, Cairo.

- Severin H.G. (1991), "Coptic Sculpture in Stone", The Coptic Encyclopedia, VII, New York.

- Shafei A. (1960), Lake Moeris and Lahûn Mi-Wer and Ro- Hûn: The Great Nile Control Project Executed by the Ancient Egyptians. Bulletin Société de Géographie D'Egypte, 33:187-217

- Shier L.A. (1978), Terracotta Lamps from Karanis, Egypt: Excavations of the University of Michigan, Ann Arbor

- Stewart J.D., Molto J.E., Reimer P.J. (2003), "The Chronology of Kellis 2: The Interpretative Significance of Radiocarbon Dating of Human Remains", The Oasis Papers 3: Proceedings of the First International Conference of the Dakhleh Oasis Project, Bowen GE, Hope CA (eds.). Oxbow Books: Oxford, 373-378.

- Strabo, Geography. Trans. by Jones H. L. (1949), Loeb Classical library, London, Book I, XVII.

- Thomas T.K. (2000), Late Antique Egyptian Funerary Sculpture, Princeton

- Van Haelst J. (1970), "Les Sources Papyro-logiques concernant l'Église en Égypte à l'Époque de Constantin", Proceedings of the Twelfth International Congress of Papyrology, ed. by Deborah H. Samuel (American Studies in Papyrology, 7, Toronto, 497-503.

- Vandier J. (1952), Manuel d'Archéologie Égyptienne. Vol.1, Paris: 1952.

- Van Minnen P. (1995), "Deserted Villages: Two Late Antique Town Sites in Egypt", BASP 32, 41-56.

- Venit M.S. (2002), Monumental Tombs of Ancient Alexandria, New York.

- Vitruvius, "On Architecture”, translated by Frank Granger, The Loeb Classical Library, London, 1931.

- Vörös G. (2001), Taposiris Magna Port of Isis, Hungary.

- Walters C.C. (1974), Monastic Archaeology in Egypt, Warminster

- Watson P.J. (1987), Egyptian Pyramids and. Mastaba Tombs, Shire Publications, England

- Wells C., Green C. (1973), "Sunrise Dating of Death and Burial". Norfolk Archaeology 35, 435-442

- Westermann W.L. (1917), "Land Reclamation in the Fayum under the Ptolemies Philadelphus and Euergetes I", Classical Philology 12.

- Wilson D.M. (1991), The Collection of the British Museum, London. 
- Youtie H.C., Schuman V.B., Pearl O.M. (1936-1939), Tax Rolls from Karanis in Two Volumes (Michigan Papyri, Vol. IV Part 111), Ann Arbor: University of Michigan Press.

- -----------, Pearl O.M. (1944), "Papyri and Ostraca from Karanis" Michigan Papyri, Vol. VI, Ann Arbor: University of Michigan Press.

- ----------, Winter J.G. (1951), "Papyri and Ostraca from Karanis", Second Series, Michigan Papyri, Vol. VIII, Ann Arbor: University of Michigan Press. 